\title{
Modeling the global emission, transport and deposition of trace elements associated with mineral dust
}

\author{
Y. Zhang ${ }^{1,2}$, N. Mahowald ${ }^{2}$, R. A. Scanza ${ }^{2}$, E. Journet ${ }^{3}$, K. Desboeufs ${ }^{3}$, S. Albani ${ }^{2}$, J. F. Kok ${ }^{4}$, G. Zhuang ${ }^{1}$, Y. Chen ${ }^{1}$, \\ D. D. Cohen ${ }^{5}$, A. Paytan $^{6}$, M. D. Patey ${ }^{7}$, E. P. Achterberg ${ }^{7,9}$, J. P. Engelbrecht ${ }^{8}$, and K. W. Fomba ${ }^{10}$ \\ ${ }^{1}$ Shanghai Key Laboratory of Atmospheric Particle Pollution and Prevention (LAP ${ }^{3}$ ), Department of Environmental Science \\ and Engineering, Fudan University, Shanghai, China \\ ${ }^{2}$ Department of Earth and Atmospheric Science, Cornell University, Ithaca, NY, USA \\ ${ }^{3}$ LISA, UMR CNRS7583, Université Paris-Est Créteil et Université Paris-Diderot, Créteil, France \\ ${ }^{4}$ Department of Atmospheric and Oceanic Sciences, University of California, Los Angeles, CA, USA \\ ${ }^{5}$ Australian Nuclear Science and Technology Organization, Locked Bag 2001, Kirrawee DC, NSW, 2232, Australia \\ ${ }^{6}$ Earth and Planetary Sciences Department, University of California, Santa Cruz, CA 95064, USA \\ ${ }^{7}$ Ocean and Earth Science, National Oceanography Centre Southampton, University of Southampton, \\ Southampton SO14 3ZH, UK \\ ${ }^{8}$ Desert Research Institute (DRI), 2215 Raggio Parkway, Reno, Nevada 89512-1095, USA \\ ${ }^{9}$ GEOMAR, Helmholtz Centre for Ocean Research, 24148 Kiel, Germany \\ ${ }^{10}$ Leibniz Institute for Tropospheric Research (TROPOS), 04318 Leipzig, Germany
}

Correspondence to: Y. Zhang (yan_zhang@fudan.edu.cn)

Received: 13 November 2014 - Published in Biogeosciences Discuss.: 17 December 2014

Revised: 12 August 2015 - Accepted: 10 September 2015 - Published: 12 October 2015

\begin{abstract}
Trace element deposition from desert dust has important impacts on ocean primary productivity, the quantification of which could be useful in determining the magnitude and sign of the biogeochemical feedback on radiative forcing. However, the impact of elemental deposition to remote ocean regions is not well understood and is not currently included in global climate models. In this study, emission inventories for eight elements primarily of soil origin, $\mathrm{Mg}, \mathrm{P}, \mathrm{Ca}, \mathrm{Mn}, \mathrm{Fe}, \mathrm{K}, \mathrm{Al}$, and $\mathrm{Si}$ are determined based on a global mineral data set and a soil data set. The resulting elemental fractions are used to drive the desert dust model in the Community Earth System Model (CESM) in order to simulate the elemental concentrations of atmospheric dust. Spatial variability of mineral dust elemental fractions is evident on a global scale, particularly for $\mathrm{Ca}$. Simulations of global variations in the $\mathrm{Ca} / \mathrm{Al}$ ratio, which typically range from around 0.1 to 5.0 in soils, are consistent with observations, suggesting that this ratio is a good signature for dust source regions. The simulated variable fractions of chemical elements are sufficiently different; estimates of deposition should include elemental variations, especially for $\mathrm{Ca}, \mathrm{Al}$
\end{abstract}

and $\mathrm{Fe}$. The model results have been evaluated with observations of elemental aerosol concentrations from desert regions and dust events in non-dust regions, providing insights into uncertainties in the modeling approach. The ratios between modeled and observed elemental fractions range from 0.7 to 1.6, except for $\mathrm{Mg}$ and $\mathrm{Mn}$ (3.4 and 3.5, respectively). Using the soil database improves the correspondence of the spatial heterogeneity in the modeling of several elements $(\mathrm{Ca}, \mathrm{Al}$ and $\mathrm{Fe}$ ) compared to observations. Total and soluble dust element fluxes to different ocean basins and ice sheet regions have been estimated, based on the model results. The annual inputs of soluble $\mathrm{Mg}, \mathrm{P}, \mathrm{Ca}, \mathrm{Mn}, \mathrm{Fe}$ and $\mathrm{K}$ associated with dust using the mineral data set are $0.30 \mathrm{Tg}, 16.89 \mathrm{Gg}$, $1.32 \mathrm{Tg}, 22.84 \mathrm{Gg}, 0.068 \mathrm{Tg}$, and $0.15 \mathrm{Tg}$ to global oceans and ice sheets. 


\section{Introduction}

Desert dust aerosols are soil particles suspended in the atmosphere by strong winds and originate primarily from regions with dry, un-vegetated soils. Desert dust particles are thought to contain several important chemical elements which can impact the earth system by influencing biogeochemical cycles and, in particular, marine primary productivity (Martin et al., 1991; Duce and Tindale, 1991; Herut et al., 1999, 2002, 2005; Okin et al., 2004; Jickells et al., 2005). Iron (Fe) is considered the most important element carried in dust, and low Fe supplies combined with a low dust solubility are thought to limit phytoplankton growth in high-nutrient low-chlorophyll (HNLC) regions. The HNLC regions feature residual macronutrient (e.g., nitrogen, N, and phosphorus, $\mathrm{P})$ concentrations, but productivity remains limited by the low supply of Fe (e.g., Martin et al., 1991; Boyd et al., 1998). Further studies have linked $\mathrm{Fe}$ to the nitrogen cycle because of high $\mathrm{Fe}$ requirements of $\mathrm{N}$ fixing organisms (e.g., Capone et al., 1997). While there are internal sedimentary sources of $\mathrm{Fe}$ in the ocean, dust deposition is an important source of new $\mathrm{Fe}$ to remote regions of the ocean (e.g., Fung et al., 2000; Lam and Bishop, 2008; Moore and Braucher, 2008). Desert dust also contains $P$, which is a limiting nutrient in some ocean and land regions (e.g., Mills et al., 2004; Okin et al., 2004; Swap et al., 1992), especially on longer timescales. In addition, as a dominant constituent of mineral dust, silicon ( $\mathrm{Si}$ ) is an important nutrient for diatoms which are central in ocean productivity (Morel et al., 2003). Other elements released from mineral dust which may be important for ocean biogeochemistry include manganese $(\mathrm{Mn})$ as a biologically essential nutrient and aluminum (Al) as a tracer of atmospheric inputs (e.g., Nozaki, 1997; http://www.geotraces.org/science/science-plan).

Previous studies have emphasized the importance of measuring elemental composition of dust elements (Kreutz and Sholkovitz, 2000; Cohen et al., 2004; Marino et al., 2004; Marteel et al., 2009), and there is a range of studies highlighting observations of elemental distributions and ecosystem impacts (e.g., Baker et al., 2003; Herut et al., 2002; Buck et al., 2006; Paytan et al., 2009; Chen and Siefert, 2004; Measures and Vink, 2000). In situ observations show evidence of heterogeneities in elemental fractions over arid soil regions (Svensson et al., 2000; Zhang et al., 2003; Shen et al., 2005, 2006; Li et al., 2007). Ratios between elements including $\mathrm{Si}, \mathrm{Al}, \mathrm{Mg}, \mathrm{Ca}$, and in particular $\mathrm{Ca} / \mathrm{Al}$ ratios have also been used to distinguish dust source regions, for example the Asian desert (Zhang et al., 1997; Sun et al., 2005; Han et al., 2005; Shen et al., 2007) and African deserts (Bergametti et al., 1989; Formenti et al., 2008).

Xuan (2005) has simulated the emission inventory of trace elements in the dust source regions of East Asia. However, there has not yet been a study to model the distribution of dust-associated elements on a global scale. Global dust models usually assume a fixed fraction (e.g., normalized to $\mathrm{Al}$ ) of each element in dust to simulate global dust elemental transport and deposition. For example, Fe is thought to contribute $3.5 \%$ and P $0.075 \%$ to mineral dust (by mass; e.g., Luo et al., 2008; Mahowald et al., 2008). Besides spatial variations in elemental compositions, particle size distribution forms another important determinant of elemental abundance in deposited dust. Depending on the particle size distribution, trace elements may remain more or less suspended in the atmosphere and deposited by dry or wet deposition at various distances from desert regions (Seinfeld and Pandis, 1998). There have been very few studies investigating particle size distribution and elemental concentrations in soil and dust by direct measurement (Schütz and Rahn, 1982; Reid et al., 2003; Castillo et al., 2008; Engelbrecht et al., 2009), and even fewer modeling studies have included this. The ability to model the deposition of specific elements associated with dust in global simulations has been hindered by a lack of understanding of the spatial and temporal variability, as well as the particle size distribution associated with different dust sources. As noted by Lawrence and Neff (2009), it seems most appropriate to use a globally averaged value of dust composition to estimate the elemental flux from dust, given the lack of direct measurements of the spatial distribution of elements in dust. However, the use of a global mineral map (Claquin et al., 1999; Nickovic et al., 2012, 2013; Journet et al., 2014) and chemical compositions of minerals (Journet et al., 2008) allows us to simulate global elemental inventories from mineral soils, which could be used in a global dust model.

This study aims at introducing a technique to determine a size-fractionated global soil elemental emission inventory based on two different data sets, a global soil data set and a mineralogical data set. A companion paper evaluates the ability of the model to simulate mineralogy and the impact on radiation (Scanza et al., 2015). The elemental emission data set estimated for $\mathrm{Mg}, \mathrm{P}, \mathrm{Ca}, \mathrm{Fe}, \mathrm{Mn}, \mathrm{K} \mathrm{Al}$, and $\mathrm{Si}$ was used as an input to a model simulation of the global dust cycle to present the elemental distributions, which were compared against available observations of concentration and deposition to different ocean regions. Our goal is to assess the variability of elemental fractions in atmospheric and deposited dust and to investigate whether the elemental emission data set can adequately predict this variability. This study focuses on desert dust particles and thus disregards other potentially important sources of the elements such as combustion processes (e.g., Guieu et al., 2005; Luo et al., 2008; Mahowald et al., 2008). We focus on total elemental concentrations but discuss two methodologies for soluble metal distributions from soil emissions. We also do not consider any atmospheric processing, which is likely to be important for some chemical components (e.g., Mahowald et al., 2005; Baker and Croot, 2010). 


\section{Materials and methods}

\subsection{Soil and mineral data sets}

The soil map of the world used in this study comes from the Food and Agriculture Organization (FAO) of the United Nations soils data set and includes 136 soil units from the FAOUnited Nations Educational, Scientific, and Cultural Organization (FAO-UNESCO, 1995) at a 5 min resolution. The global data set of soil clay and silt data are used in this study. Following Claquin et al. (1999) and Nickovic et al. (2012), the illite, hematite, kaolinite, smectite, quartz, feldspars, calcite and gypsum contents are specified for different clay and silt soil types, and the global mineral distribution is presented in Scanza et al. (2015). Some minerals found in dust such as dolomite were not considered by Claquin et al. (1999) and Nickovic et al. (2012) and have also been disregarded in this study due to the lack of data on their distribution.

The elemental compositions of hematite and aluminosilicate minerals used in this study are taken from previous works (Journet et al., 2008, and unpublished data provided by E. Journet, 2012) and were obtained by X-ray fluorescence spectrometry (XRF; Table 1a). Most of the minerals used by Journet et al. (2008) are reference materials from the Clay Minerals Society's Source Clays Repository, i.e., hematite, illite, kaolinite, and montmorillonite. The elemental compositions obtained by XRF are in the range of published values for these reference materials (e.g., Mermut and Cano, 2001; Gold et al., 1983), validating the obtained composition for the unreferenced materials. Moreover, the purity of all mineral samples is estimated by X-ray diffraction. Note that the mineralogical maps used in this study do not distinguish feldspar and smectite subtypes. For feldspars, the elemental composition is mostly averaged based on two subtype minerals: orthoclase (potassic feldspar) and oligoclase (sodiumcalcium feldspar). For smectites, the montmorillonite subtype is the most commonly identified smectite in desert dust, particularly for Saharan dust (e.g., Goudie and Middleton, 2006). The chemical composition of montmorillonite is used in this study as an analog for smectite. For calcite, gypsum, and quartz, the natural minerals could contain substitutions or impurities from clays, which are variable depending on origin, formation, contamination, etc., of minerals. Because regional silt samples were not available for spectroscopy, we use the theoretical composition of elements in calcite, gypsum and quartz (Table 1a). The mass fractions of $\mathrm{Ca}$ in calcite $\left(\mathrm{CaCO}_{3}\right)$ and gypsum $\left(\mathrm{CaSO}_{4} \times 2 \mathrm{H}_{2} \mathrm{O}\right)$ are taken as 40 and $23.3 \%$, respectively. A mass fraction of $46.7 \% \mathrm{Si}$ is used for pure quartz $\left(\mathrm{SiO}_{2}\right)$.

Following the total element calculation, soluble elemental fractions are estimated based on soluble elemental contents of minerals at $\mathrm{pH}=2$ reported by Journet et al. (2008) for hematite and the aluminosilicates and are listed in Table $1 \mathrm{~b}$. The fractional solubility of $\mathrm{Ca}$ used in calcite and gypsum was 7 and $0.56 \%$, respectively, and that of $\mathrm{Si}$ in quartz was $0.0003 \%$ based on the individual solubility product $\left(\mathrm{K}_{\mathrm{sp}}\right)$ at $\mathrm{pH}=2$ (Petrucci et al., 2011). Here the mineraldependent method used to calculate soluble elements is defined as Method 1 (Sol-1). To present uncertainties, another approach (Method 2, defined as Sol-2) is introduced as a reference. It is based on the extractable elemental fractions of in situ $20 \mu \mathrm{m}$ sieved soil samples reported by Sillanpää (1982; Table S1 in the Supplement) and is combined with an FAO soil data set to get a global soluble elemental inventory independent of soil minerals. It is noted that there is no detailed size distribution for soil samples in Sol-2. Thus, the fractions of soluble elements in clay and silt are assumed to be equal to those of the bulk soils themselves.

One drawback of our approach is that we disregard the large variability of soils included within each defined "soil type". The range of minerals within each soil type is large (e.g., Claquin et al., 1999), and the range of elemental concentrations in each mineral is also large (Journet et al., 2008). The resolution of our model is such that despite the actual heterogeneity of soils at a particular location, we prescribe an average at each grid box which tends to reduce the variability of the elemental composition in the mineral dust in the atmosphere. This is likely to be the largest source of uncertainty in our approach.

\subsection{Numerical model description}

The Community Earth System Model version 1.0.3 (CESM1.0.3) is coordinated by the National Center for Atmospheric Research (NCAR), and has been used to simulate elemental dust emission, transport and deposition in this study. The bulk mineral aerosol in the Community Atmosphere Model version 4 (CAM4) was adapted to include eight trace elements within total dust (Scanza et al., 2015). In this model simulation, the physical scheme CAM4 is driven by the meteorological data set MERRA (Modern Era Retrospective-Analysis) and is simulated spatially at $1.9 \times 2.5^{\circ}$ resolution for the years $2000-2010$. The soil erodibility map used by the dust model has been spatially tuned (Albani et al., 2014). There are four size classes of dust particles used in the dust emission module in the bulk scheme with particle diameters of $0.1-1.0,1.0-2.5,2.5-5.0$ and $5.0-10.0 \mu \mathrm{m}$. The sub-bin size distribution is assumed to follow a log-normal distribution with a mass median diameter of $3.5 \mu \mathrm{m}$ (Mahowald et al., 2006) and a geometric standard deviation of $2.0 \mu \mathrm{m}$ (Zender et al., 2003). Combining these log-normal parameters with the brittle fragmentation theory of dust emission (Kok, 2011) yields each bin's partitioning of dust aerosol mass between the soil's clay and silt size fractions (see Table 3 and Scanza et al., 2015). The elements in the dust undergo three-dimensional transport individually in each of the different size bins, identically to bulk dust in the original model. Elemental atmospheric mixing ratios, and wet and dry deposition are updated at each 
Table 1. (a) Generalized mineral compositions (\%) applied in this study. (b) Elemental solubility as a percentage of the element contained in the minerals $(\%)$.

\begin{tabular}{|c|c|c|c|c|c|c|c|c|}
\hline \multicolumn{9}{|l|}{ (a) } \\
\hline Mineral & $\mathrm{Mg}$ & $\mathrm{P}$ & $\mathrm{Ca}$ & $\mathrm{Mn}$ & $\mathrm{Fe}$ & $\mathrm{Al}$ & $\mathrm{Si}$ & K \\
\hline Smectite & 1.21 & 0.17 & 0.91 & 0.03 & 2.55 & 8.57 & 27.44 & 0.27 \\
\hline Illite & 0.85 & 0.09 & 1.45 & 0.03 & 4.01 & 10.47 & 24.11 & 4.28 \\
\hline Hematite & 0.09 & 0.18 & 0.12 & 0.07 & 57.50 & 2.67 & 2.11 & 0.07 \\
\hline Feldspar & 0.15 & 0.09 & 3.84 & 0.01 & 0.34 & 10.96 & 25.24 & 5.08 \\
\hline Kaolinite & 0.02 & 0.16 & 0.03 & 0.01 & 0.24 & 20.42 & 20.27 & 0.00 \\
\hline Calcite & 0.00 & 0.00 & 40.00 & 0.00 & 0.00 & 0.00 & 0.00 & 0.00 \\
\hline Quartz & 0.00 & 0.00 & 0.00 & 0.00 & 0.00 & 0.00 & 46.70 & 0.00 \\
\hline Gypsum & 0.00 & 0.00 & 23.30 & 0.00 & 0.00 & 0.00 & 0.00 & 0.00 \\
\hline
\end{tabular}

\begin{tabular}{lrrrrrrrr}
\hline (b) & \multicolumn{1}{c}{$\mathrm{C}$} & \multicolumn{1}{c}{$\mathrm{Al}$} & $\mathrm{Si}$ & $\mathrm{K}$ \\
\hline Mineral & $\mathrm{Mg}$ & $\mathrm{P}$ & $\mathrm{Ca}$ & $\mathrm{Mn}$ & $\mathrm{Fe}$ & $\mathrm{Al}$ & \\
\hline Smectite & 14.09 & 2.93 & 79.20 & 25.35 & 2.60 & 0.00 & 0.05 & 31.41 \\
Illite & 7.80 & 30.58 & 50.96 & 24.93 & 1.17 & 0.15 & 0.05 & 2.87 \\
Hematite & 0.00 & 0.00 & 0.00 & 3.39 & 0.01 & 0.00 & 0.00 & 0.00 \\
Feldspar & 5.17 & 0.00 & 4.46 & 4.71 & 3.01 & 0.12 & 0.02 & 4.53 \\
Kaolinite & 22.32 & 0.00 & 21.97 & 0.00 & 4.26 & 0.38 & 0.37 & 0.00 \\
Calcite & 0.00 & 0.00 & 7.00 & 0.00 & 0.00 & 0.00 & 0.00 & 0.00 \\
Quartz & 0.00 & 0.00 & 0.00 & 0.00 & 0.00 & 0.00 & 0.0003 & 0.00 \\
Gypsum & 0.00 & 0.00 & 0.56 & 0.00 & 0.00 & 0.00 & 0.00 & 0.00 \\
\hline
\end{tabular}

Note: Fe content came from Journet et al. (2008), the other elements were from personal communication with E. Journet, 2012

model time step based on actual elemental fields and the corresponding tendencies.

There has been considerable work on improving advection algorithms in atmospheric models, and here we use the finite volume advection algorithm as part of the CAM (Lin and Rood, 1997). While no advection scheme is perfectly mass conserving, monotonic, shape preserving and computationally efficient, this scheme does a good job of balancing these multiple goals and maintaining strong gradients required in modeling atmospheric constituents (e.g., Rasch et al., 2006). By splitting the dust into its different mineral elements, we may add in additional numerical errors, because the advection will not conserve the fraction of elements within dust aerosols due to small numerical errors. For the discussion of the ratios of elements, it would be better to advect the minerals themselves, and evaluate the ratio of elements later, since this would better conserve the ratios. Studies focused on elemental ratios and their distribution in ocean models have suggested there is a relatively small uncertainty associated with these types of numerical errors (e.g., Christian, 2007) and, compared with the errors in the source distribution of the minerals, errors from advection are likely to be small and are neglected here.

\subsection{Observational data}

An element data set of ground-based aerosol measurements at 17 sites (Table S3) is used to evaluate the elemental dust simulation (Sun et al., 2004a, b; Wang et al., 2010; Chen et al., 2008; Engelbrecht et al., 2009; Carpenter et al., 2010; Cohen et al., 2011; Guo et al., 2014; Formenti et al., 2008; Desboeufs et al., 2010). The sites are close to major dustproducing regions (Fig. 1), including 10 Asian sites (Central Asia: Hetian, Tazhong; East Asia: Yulin, Duolun, Shengsi; South Asia: Hanoi, and Manila; Middle East: Balad, Baghdad, Taji), 5 African sites (West Africa: Cape Verde Atmospheric Observatory (CVAO); East Africa: Eilat; North Africa: Tamanrasset, Banizoumbou, and Douz), and 2 Australian sites (Muswellbrook and Richmond). Generally, these field aerosol samples (total suspended particulates (TSPs), $\mathrm{PM}_{10}, \mathrm{PM}_{2.5}$ ) had 1-3 day collection periods during the period 2001-2010 and were chemically analyzed for elemental composition. No observational aerosol mass concentrations at the Cape Verde station could be used in this study. At this site, the particulate matter (PM) concentrations are estimated by assuming an $\mathrm{Al}$ to total dust mass ratio of 0.0804 . In order to be certain that only desert dust elements are compared with the model results, only data collected during dust storm seasons are selected. Measurement sites from which data are taken are listed in Table S3, which includes related methodological details. 
Table 2. Ten-year-averaged emission rates $\left(\mathrm{Tg} \mathrm{yr}^{-1}\right)$ and percentages of elements over desert regions. (For this table, annual mean emission of each element is divided by the annual mean emission of dust to obtain the percentage).

\begin{tabular}{|c|c|c|c|c|c|c|c|c|c|}
\hline Source regions & $\mathrm{Mg}$ & $\mathrm{P}$ & $\mathrm{Ca}$ & $\mathrm{Mn}$ & $\mathrm{Fe}$ & $\mathrm{K}$ & $\mathrm{Al}$ & $\mathrm{Si}$ & Dust \\
\hline WAsia & 0.91 & $1.77 \mathrm{E}-01$ & 12.73 & $3.53 \mathrm{E}-02$ & 5.53 & 3.70 & 16.71 & 72.43 & 251.17 \\
\hline NC-As & 0.50 & $9.27 \mathrm{E}-02$ & 6.05 & $1.80 \mathrm{E}-02$ & 2.26 & 1.90 & 8.36 & 37.99 & 128.59 \\
\hline CAsia & 0.13 & $2.54 \mathrm{E}-02$ & 1.57 & $4.98 \mathrm{E}-03$ & 0.70 & 0.55 & 2.35 & 9.77 & 33.82 \\
\hline SC-As & 0.05 & $1.07 \mathrm{E}-02$ & 0.54 & $1.93 \mathrm{E}-03$ & 0.29 & 0.22 & 1.04 & 4.07 & 13.91 \\
\hline EAsia & 0.21 & 4.38E-02 & 1.62 & $8.16 \mathrm{E}-03$ & 1.28 & 0.85 & 4.22 & 18.27 & 58.90 \\
\hline Asian Region & 1.79 & $3.50 \mathrm{E}-01$ & 22.52 & $6.84 \mathrm{E}-02$ & 10.06 & 7.23 & 32.67 & 142.54 & 486.4 \\
\hline EN-Af & 1.23 & 2.74E-01 & 11.98 & 4.83E-02 & 6.62 & 5.41 & 26.45 & 102.59 & 346.16 \\
\hline WN-Af & 2.62 & $5.31 \mathrm{E}-01$ & 30.67 & $1.01 \mathrm{E}-01$ & 14.25 & 11.04 & 50.35 & 208.70 & 712.00 \\
\hline S-NAf & 0.02 & $1.17 \mathrm{E}-02$ & 0.17 & $1.47 \mathrm{E}-03$ & 0.37 & 0.12 & 1.25 & 4.33 & 13.98 \\
\hline SAf & 0.01 & $3.10 \mathrm{E}-03$ & 0.18 & $5.90 \mathrm{E}-04$ & 0.11 & 0.06 & 0.31 & 1.34 & 4.46 \\
\hline African Region & 3.89 & $8.20 \mathrm{E}-01$ & 42.99 & $1.51 \mathrm{E}-01$ & 21.34 & 16.63 & 78.36 & 316.96 & 1076.6 \\
\hline MWNAm & 0.00002 & $4.70 \mathrm{E}-06$ & 0.0001 & $8.00 \mathrm{E}-07$ & 0.0002 & 0.0001 & 0.0005 & 0.0019 & 0.030 \\
\hline SWNAm & 0.02 & $3.01 \mathrm{E}-03$ & 0.16 & $6.00 \mathrm{E}-04$ & 0.10 & 0.07 & 0.29 & 1.27 & 4.20 \\
\hline North America & 0.02 & $3.02 \mathrm{E}-03$ & 0.16 & $6.00 \mathrm{E}-04$ & 0.10 & 0.07 & 0.29 & 1.27 & 4.2 \\
\hline SAm1 & 0.0005 & $1.20 \mathrm{E}-04$ & 0.01 & $2.00 \mathrm{E}-05$ & 0.003 & 0.002 & 0.01 & 0.04 & 0.15 \\
\hline SAm2 & 0.03 & $6.79 \mathrm{E}-03$ & 0.27 & $1.32 \mathrm{E}-03$ & 0.20 & 0.13 & 0.62 & 2.82 & 9.08 \\
\hline South America & 0.03 & $6.91 \mathrm{E}-03$ & 0.27 & $1.34 \mathrm{E}-03$ & 0.21 & 0.13 & 0.63 & 2.86 & 9.2 \\
\hline WAus & 0.0005 & $1.30 \mathrm{E}-04$ & 0.003 & $2.00 \mathrm{E}-05$ & 0.003 & 0.002 & 0.01 & 0.05 & 0.16 \\
\hline EAus & 0.02 & $5.13 \mathrm{E}-03$ & 0.20 & $9.10 \mathrm{E}-04$ & 0.16 & 0.10 & 0.48 & 1.78 & 6.11 \\
\hline Australia Region & 0.02 & $5.26 \mathrm{E}-03$ & 0.20 & $9.30 \mathrm{E}-04$ & 0.17 & 0.10 & 0.49 & 1.83 & 6.3 \\
\hline Global & 5.75 & $1.18 \mathrm{E}+00$ & 66.14 & $2.22 \mathrm{E}-01$ & 31.87 & 24.15 & 112.44 & 465.46 & 1582.7 \\
\hline Global mean \% element & 0.36 & 0.07 & 4.18 & 0.01 & 2.01 & 1.53 & 7.10 & 29.41 & - \\
\hline Min. \% element in $15 \mathrm{SR}^{*}$ & 0.17 & 0.07 & 1.19 & 0.01 & 1.67 & 0.86 & 6.50 & 28.84 & - \\
\hline Max. \% element in $15 \mathrm{SR}^{*}$ & 0.39 & 0.08 & 5.07 & 0.02 & 2.68 & 1.63 & 8.96 & 31.38 & - \\
\hline
\end{tabular}

* SR refers to source regions (WAsia: West Asia; NC-As: North Central Asia; CAsia: Central Asia; SC-As: South Central Asia; EAsia: East Asia; WN-Af: North West Africa; EN-Af: North East Africa; S-NAf: Southern North Africa; SAf: Southern Africa; MWNAm: Middle West North America; SWNAm: South West North America; SAm1: Northern South America; SAm2: Southern South America; WAus: West Australia; EAus: East Australia).

Table 3. Comparison of modeled and observed fractions of chemical elements in TSP, and tuning ratio based on 13 site measurements. (For this table comparing the elemental ratios at the measurement sites, the percentage value at each time measured is averaged across time and space for this comparison.).

\begin{tabular}{lrrrrrrr}
\hline & $\mathrm{Mg}$ & $\mathrm{P}$ & $\mathrm{Ca}$ & $\mathrm{Mn}$ & $\mathrm{Fe}$ & $\mathrm{K}$ & $\mathrm{Al}$ \\
\hline Corr. coeff. of averaged fractions & 0.14 & -0.32 & 0.75 & -0.51 & 0.29 & -0.16 & 0.72 \\
Median of obs. (\%) & 1.45 & 0.09 & 5.42 & 0.070 & 3.10 & 1.79 & 5.26 \\
Median of mod. (\%) & 0.43 & 0.08 & 3.41 & 0.020 & 2.29 & 1.54 & 7.81 \\
Obs./mod. median ratio (tuned ratio) & 3.4 & 1.1 & 1.6 & 3.5 & 1.4 & 1.2 & 0.7 \\
\hline
\end{tabular}

In addition, the data set of dust deposition at more than 100 sites worldwide is used to evaluate modeled dust deposition fluxes (Albani et al., 2014).

\section{Results and discussion}

\subsection{Fractions of element in arid soil regions}

The global distributions of the elements $\mathrm{Mg}, \mathrm{P}, \mathrm{Ca}, \mathrm{Mn}, \mathrm{Fe}$, $\mathrm{K}, \mathrm{Al}$, and $\mathrm{Si}$ in bulk soils as mass percentages in soils are presented in Fig. 2.

\subsubsection{Global mapping of soil-associated elements}

Fractions of elements in soils vary between mineralogical clay and silt fractions. Spatial variability of soil chemistry is seen on a global scale (Fig. 2). A large range of variability for some elements within one given source region is observed (e.g., $\mathrm{Ca}, \mathrm{Fe}, \mathrm{Mn}, \mathrm{Al}$ ). The most extreme variability is observed for $\mathrm{Ca}$ in soil silt, which varied from 0.5 to $34.3 \%$, and is much higher in West and Central Asia, South Africa and Northern South America than in other parts in the world. This is ascribed to the presence of feldspar and gypsum, both being important source minerals for $\mathrm{Ca}$ in these regions. In Central and East Asia, the Ca content increased from east 


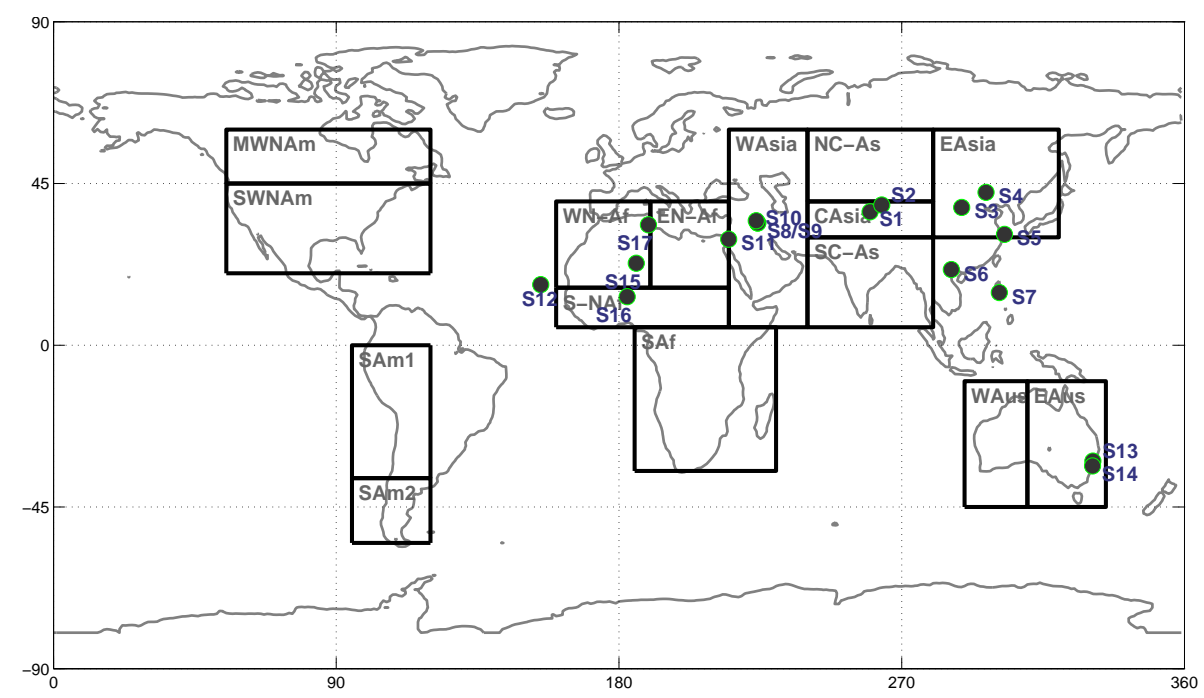

Figure 1. Observational sites (S1-Hetian, China; S2-Tazhong, China; S3-Yulin, China; S4-Duolun, China; S5-Shengsi, China; S6-Hanoi, Vietnam; S7-Manila, Philippines; S8-Balad, Iraq; S9-Baghdad, Iraq; S10-Taji, Iraq; S11-Eilat; S12-Cape Verde Atmospheric Observatory (CVAO); S13-Muswellbrook, Australia; S14-Richmond, Australia; S15-Tamanrasset, Algeria; S16-Banizoumbou, Niger; S17-Douz, Tunisia) and dust-producing regions (WAsia: West Asia; NC-As: North Central Asia; CAsia: Central Asia; SC-As: South Central Asia; EAsia: East Asia; WN-Af: North West Africa; EN-Af: North East Africa; S-NAf: Southern North Africa; SAf: Southern Africa; MWNAm: Middle West North America; SWNAm: South West North America; SAm1: Northern South America; SAm2: Southern South America; WAus: West Australia; EAus: East Australia).

to west, showing a similar spatial trend to that reported by Xuan (2005). A south to north gradient of $\mathrm{Ca}$ content was also observed in the Sahara following the carbonate distribution of soils (Kandler et al., 2007; Formenti et al., 2011). In southern North Africa, South Africa and the Western Australia, clay soil and fine dust emissions have higher $\mathrm{Al}$ and $\mathrm{P}$ concentrations than elsewhere. In Eastern Australia, Patagonia, and the northern South Africa, the Fe content of soils is also higher than in other regions. Due to their high content of quartz, soils generally have $25-40 \% \mathrm{Si}$. These elemental distributions are in agreement with other published data for $\mathrm{Fe}$, as they are derived from similar regions (e.g., Claquin, 1999; Hand et al., 2004).

\subsubsection{Elemental composition of soils and airborne dust}

Trace elements in soils show different associations with particle size patterns depending on the size distribution of soil minerals. For example, $\mathrm{Mg}, \mathrm{P}, \mathrm{Fe}, \mathrm{Mn}$, and $\mathrm{Al}$ are dominant in the clay size fraction $(<2 \mu \mathrm{m}$; Fig. $3 \mathrm{~b})$. Fractions of $\mathrm{Al}$ and Fe reach 11.7 and $3.1 \%$ in clay fractions of soils, while only 2.8 and $1.2 \%$ in silt fractions of soils, respectively. However, $\mathrm{Ca}$ and $\mathrm{Si}$ show a slight enrichment in coarser soil fractions. Ca comprises $2.6 \%$ of soils in the clay fraction but $3.6 \%$ in the soil silt fractions. This is consistent with the size distribution of $\mathrm{Ca}$ and $\mathrm{Fe}$-rich individual particle groupings measured in Saharan dust (Reid et al., 2003). K has nearly equal distributions in clay and silt fractions of soils. Taking the fractions of elements in soils as inputs, the fraction ele- ments in dust emission can be predicted. Our classification of soil particles into four aerosol sizes (Table S2) provides heterogeneity in elements across sizes but allows for a mixing across soil sizes, reducing the differences among size fractions. For example, the percentage of Fe remains unchanged from clay soil to fine-mode dust emission, but changes substantially from silt soil (1.2\%) to coarse mode dust (2.2\% in bin 3). A similar pattern appears for the other elements, and the differences between elemental percentages in the soils are reduced when dust emissions are considered (Fig. 3a vs. 3b).

\subsubsection{Elemental dust emissions over desert regions}

Annual elemental dust emissions over 15 dust-producing regions (shown in Fig. 1) are determined (Table 2). The annual average of total global dust emission is estimated to be $1582 \mathrm{Tg}$ based on 2001-2010 simulations and is within the wide range (514-5999 $\mathrm{Tg} \mathrm{yr}^{-1}$ ) as reported by previous studies (e.g., Textor et al., 2006, 2007; Prospero et al., 2010; Huneeus et al., 2011). Africa and Asia account for 68 and $31 \%$ of the global emissions, respectively. Correspondingly, trace element emissions are dominant from African desert regions, with percentages ranging between 65 and $70 \%$. Specifically, Al emissions from Africa account for $70 \%$ of global Al emissions, of which $64 \%$ originated from the western Sahara. For Asian desert regions, elemental dust accounts for $29-34 \%$ of the global total amount, with Ca being the strongest contributor (34\%) to global Ca emissions. The percentage of $\mathrm{Fe}$ is similar to $\mathrm{Al}$ in the total dust emissions 
a1. Clay Mg
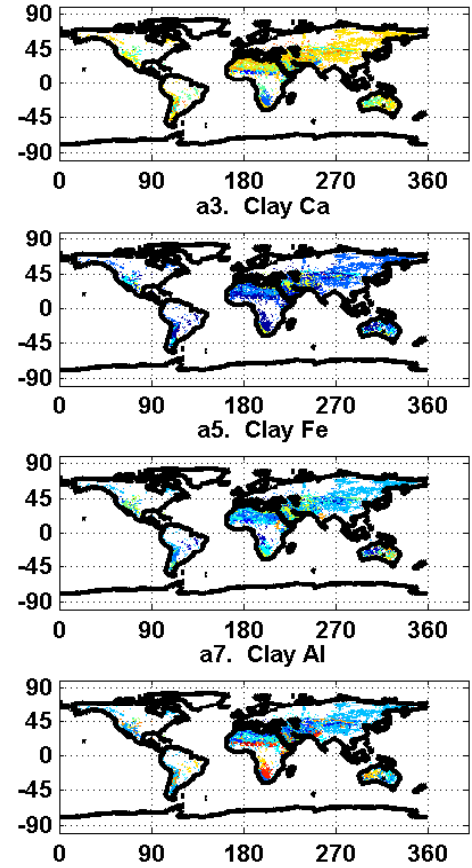

b1. Silt Mg
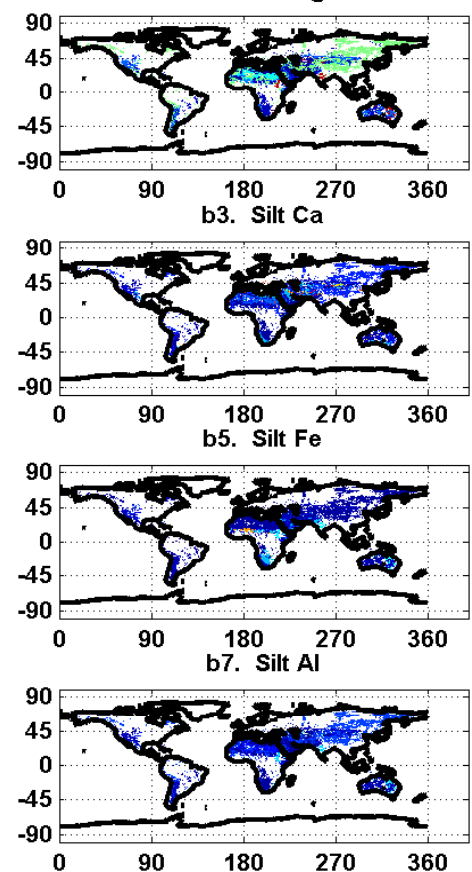

a2. Clay $P$
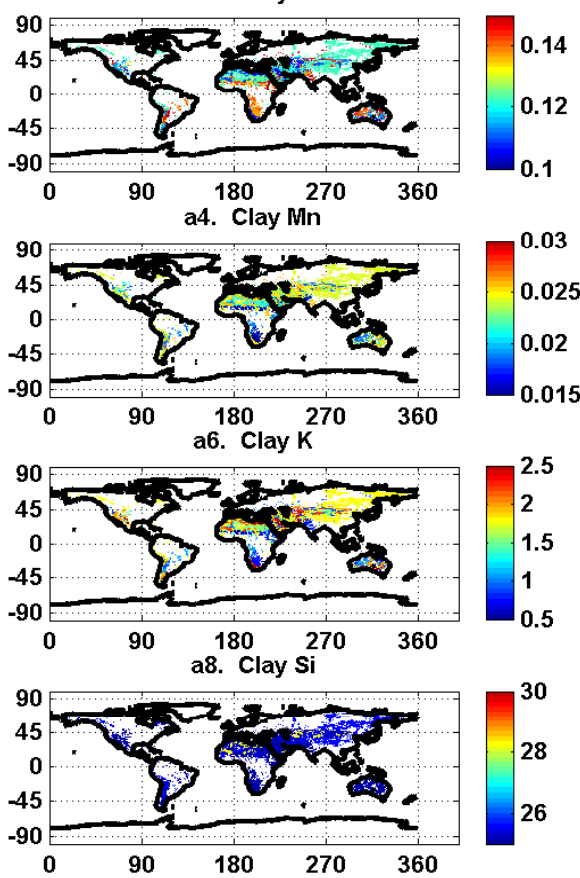

b2. Silt $\mathbf{P}$
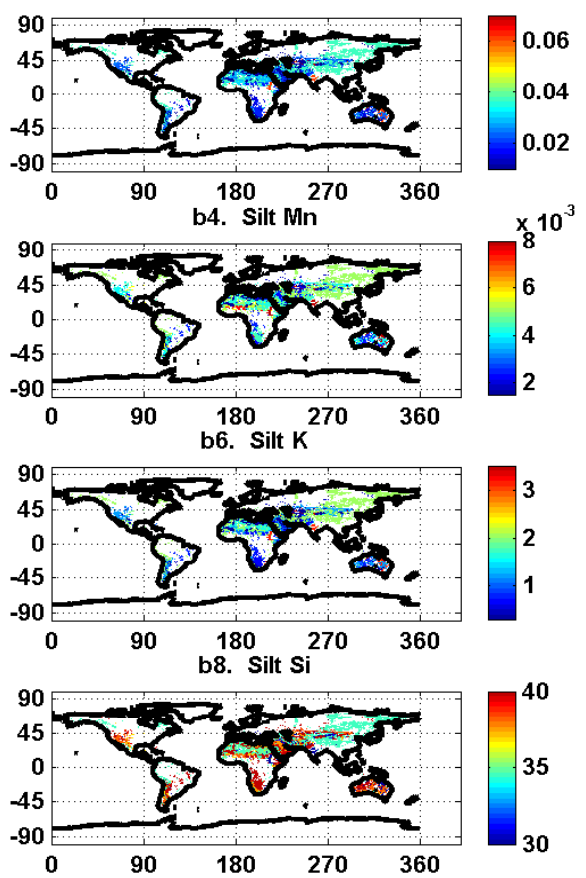

Figure 2. Global elemental distributions (in mass percentage) in a1: Clay Mg, a2: Clay P, a3: Clay Ca, a4: Clay Mn, a5: Clay Fe, a6: Clay K, a7:, Clay A1, a8: Clay Si; b1: Silt Mg, b2: Silt P, b3: Silt Ca, b4: Silt Mn, b5: Silt Fe, b6: Silt K, b7: Silt Al, b8: Silt Si. 

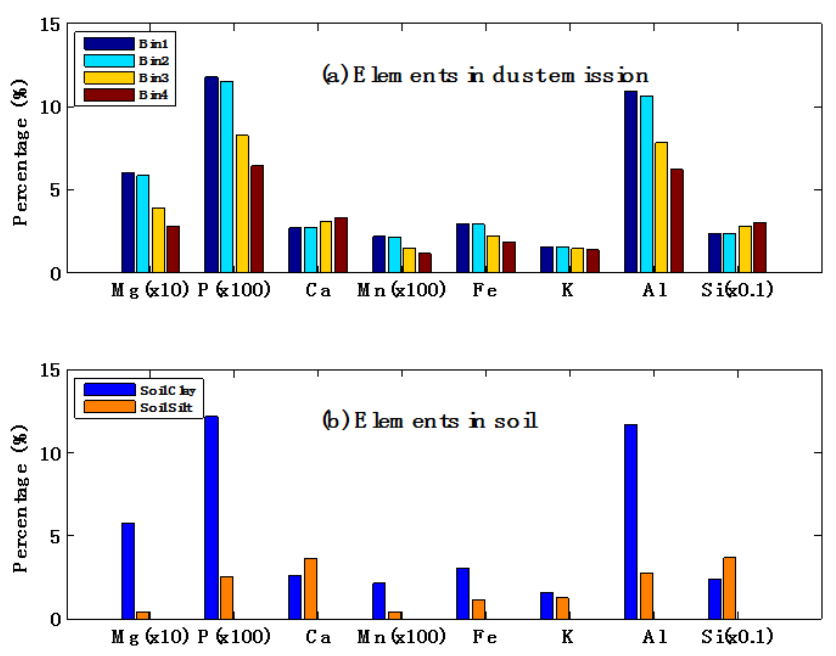

Figure 3. Global mean elemental percentages in (a) four-bin dust emission and (b) clay and silt fractions of soils (bins 1-4 refer to particle range listed in Table S2, clay refers to $<2 \mu \mathrm{m}$, silt refers to $>2 \mu \mathrm{m})$.

with 67 and $32 \%$ of Fe from Africa and Asia, respectively. The maximum percentage element for $\mathrm{Ca}$ at $5 \%$ was in dust emission from West Asia, being more than 4 times higher than Southern North Africa (1.2\%). However, the fraction of $\mathrm{Al}$ and $\mathrm{Si}$ is largest in dust emission from Southern North Africa, with values of 9.0 and $31 \%$, respectively. The fractions of $\mathrm{Fe}$ and $\mathrm{P}$ are 2.8 and $0.08 \%$ in Australia, which is higher than that in other source regions. The simulated elemental fractions in dust suggest that differentiating elements in soils between global source areas is necessary and meaningful.

\subsection{Spatial and seasonal distribution in fractions of elements in atmospheric and deposited dust}

\subsubsection{Elemental fractions in global atmospheric dust and deposited dust}

The modeled fractions of different elements in atmospheric dust have substantial spacial variability (Fig. 4). Fe content is greater than $2 \%$ for most regions, with a global mean of $2.7 \%$ in atmospheric dust. The maximum contributions of $\mathrm{Fe}, \mathrm{Al}, \mathrm{P}$ and $\mathrm{Mn}$ fractions are observed in the tropical Pacific region with values greater than $3,10,0.08$, and $0.02 \%$, respectively. For $\mathrm{Ca}, \mathrm{Si}$ and $\mathrm{K}$, a higher fraction is evident in terrestrial environments. There are obvious landocean gradients existing in the distributions of elemental fractions, with higher $\mathrm{Ca}$ and $\mathrm{Si}$ fractions in terrestrial regions and higher $\mathrm{P}, \mathrm{Fe}$, and $\mathrm{Al}$ fractions in oceanic areas, likely due to their differences in particle size distribution (Fig. 3). There are very similar spatial patterns and magnitudes shown for the elemental fractions in deposited dust compared with those in atmospheric dust for each element
(Fig. S1 in the Supplement, 5). Higher fractions of $\mathrm{Ca}$ and $\mathrm{Si}$ in deposited dust is observed in regions close to desert dust sources where the two elements occur in the coarser size fractions. Conversely, lower $\mathrm{Mg}, \mathrm{P}, \mathrm{Mn}, \mathrm{Fe}$ and $\mathrm{Al}$ contents are found in dust deposits close to source regions but higher contents are found over oceans, which is consistent with the clay soil fraction dominating the finer particle size fractions. The importance of relative location of the source compared to the deposition to the elemental ratio adds complexity in applying simple percentages to dust deposition to obtain elemental deposition amounts.

\subsubsection{Seasonal variability of elemental fractions}

As described above, the fractions of elements in dust fluctuate temporally and spatially on a global scale. There are seasonal variations in dust emissions from various desert regions showing different emission patterns (Fig. S2). The peak periods for dust emissions for various desert regions are consistent with those found by Werner et al. (2002; Fig. S2). Combining the seasonal cycles in atmospheric dust production with the element distributions in desert regions, the elemental fractions show large monthly variability but small inter-annual variability during 2001-2010 (Fig. S3). Ca and $\mathrm{Al}$ have clear seasonal cycles, with $\mathrm{Ca}$ having the largest monthly variability with peak concentrations in between July and September. This is ascribed to the higher Ca content of dust originating in West Asia, Central Asia and Southern Africa, regions that provide large global dust emissions in this period (JJAS). For the other elements, the peak concentrations usually occurred between March and May (MAM) or November through January (NDJ), corresponding to the periods when global dust emissions reach a maximum.

We modeled the seasonal variability of these elemental fractions. Elemental percentages are calculated using the climatological monthly mean emission of each element divided by the climatological monthly mean emission of dust. An index describing monthly variability is calculated as

Monthly variability (\%)

$$
=\frac{\text { SD of } 12 \text { monthly fractions }}{\text { Mean of 12-month fractions }} \times 100 \text {. }
$$

Twelve monthly mean fractions are averaged from the 10year simulation, with the corresponding standard deviations (SDs). Finally, the percentages (Eq. 1) of the standard deviation in the monthly means is derived to describe the variability in elemental fractions of atmospheric dust and deposited dust (Figs. 6, 7).

The monthly mean variation is greatest for $\mathrm{Ca}$, reaching more than $30 \%$ variability in some regions. The temporal variability of elemental percentages in deposited dust tended to be larger than those in atmospheric dust and show a greater spatial gradient from land to sea. That is similar to the trend of the elemental fractions in atmospheric and deposited dust (Sect. 3.2.1) since the temporal variation is orig- 

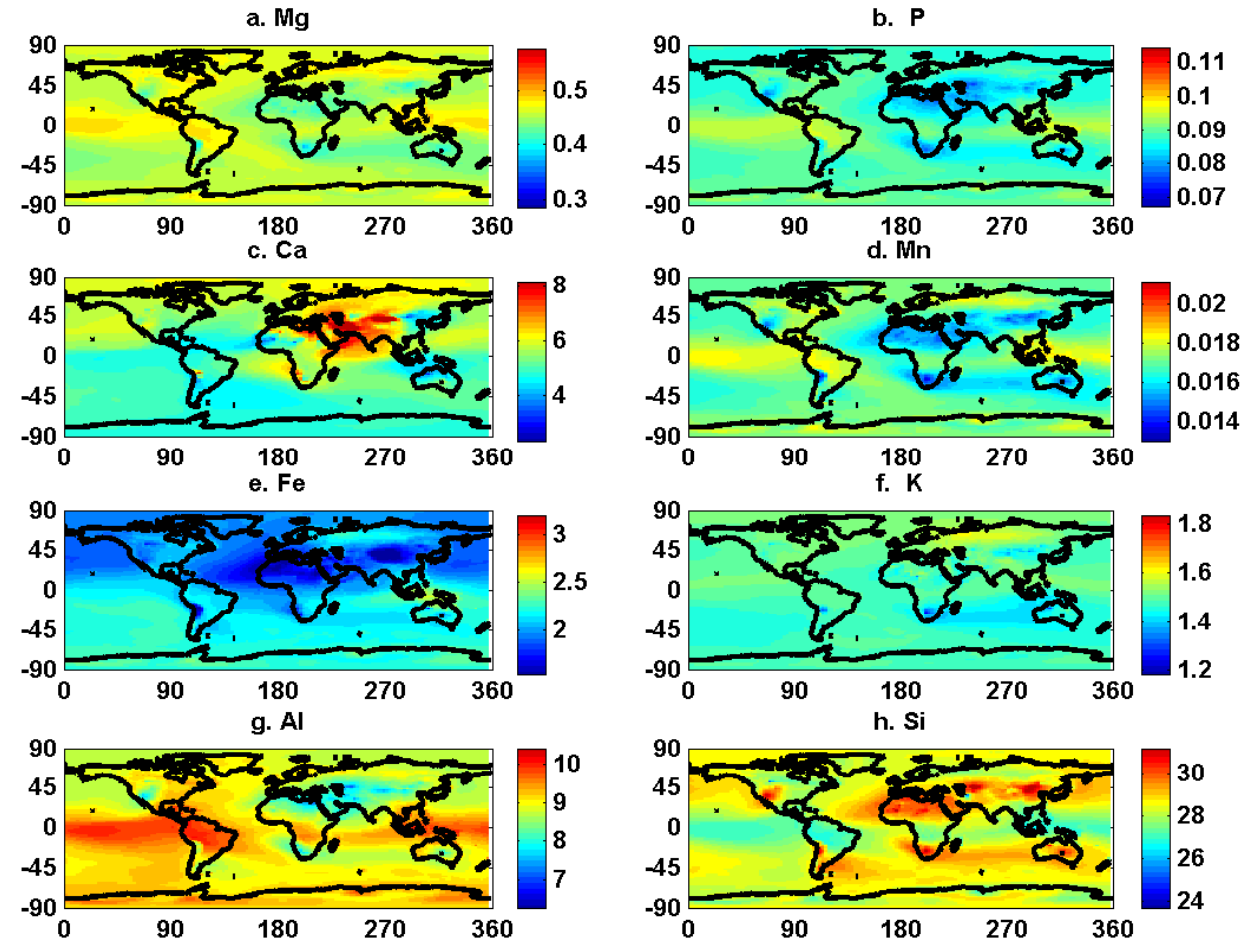

Figure 4. Percentages of elements in dust concentration (mass \%): (a) Mg, (b) P, (c) Ca, (d) Mn, (e) Fe, (f) K, (g) Al, (h) Si. Elemental percentages shown here are calculated using the annual mean element concentration divided by the annual mean dust concentration.
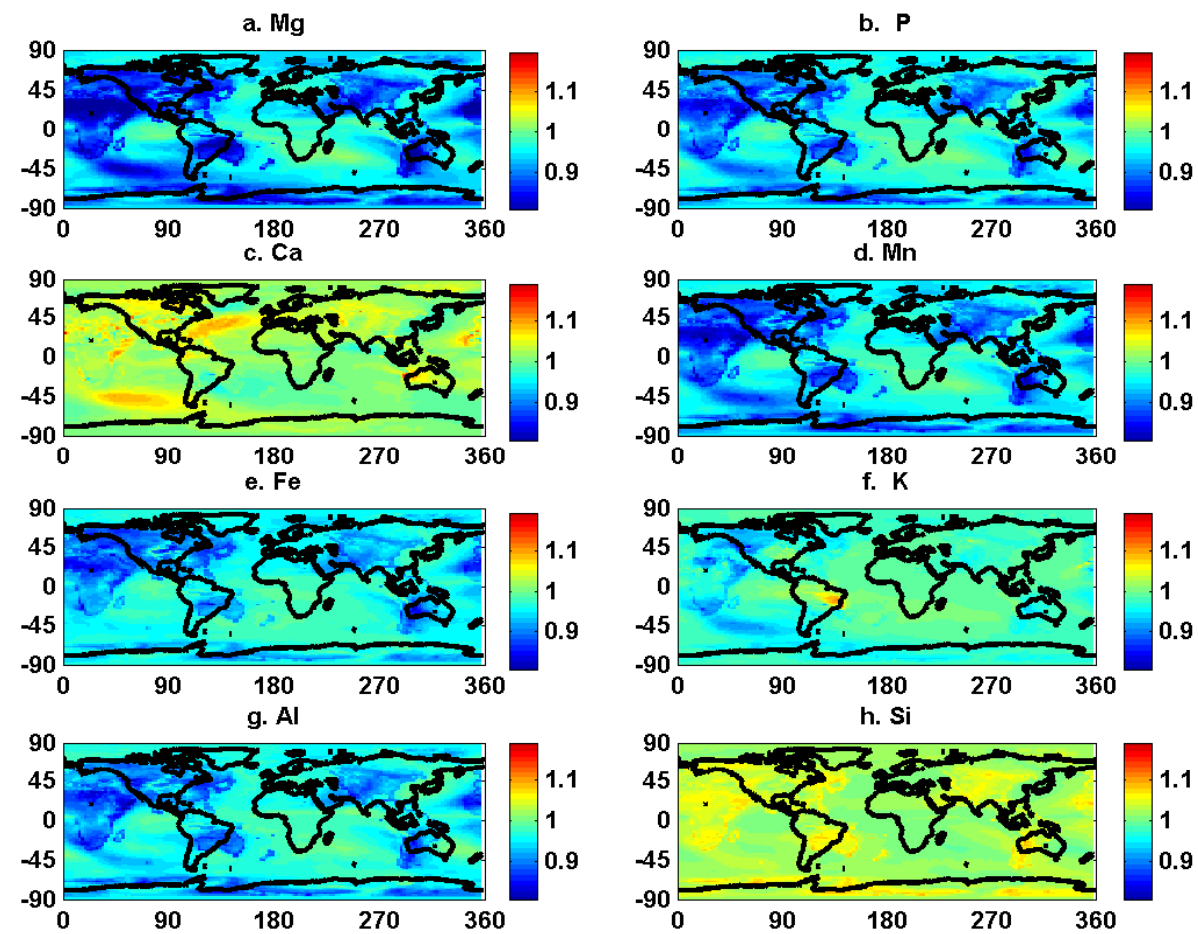

Figure 5. Ratio of mass fractions of elements in dust deposition to that in atmospheric dust: (a) $\mathrm{Mg}$, (b) $\mathrm{P}$, (c) $\mathrm{Ca}$, (d) $\mathrm{Mn}$, (e) Fe, (f) $\mathrm{K}$, (g) $\mathrm{Al}$, (h) Si. Elemental ratios shown here are calculated using the annual mean element deposition divided by the annual mean dust deposition. 
a. $\mathrm{Mg}$
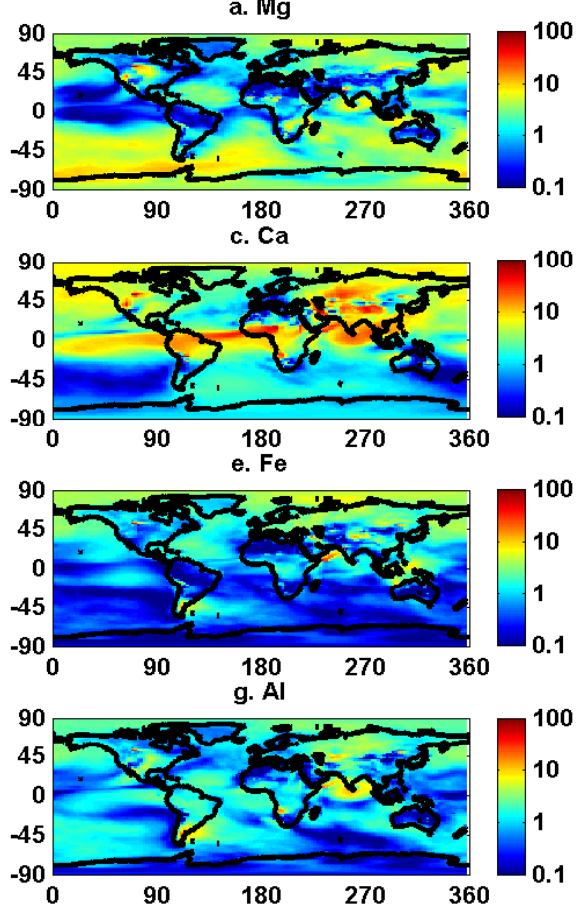

b. $\mathbf{P}$
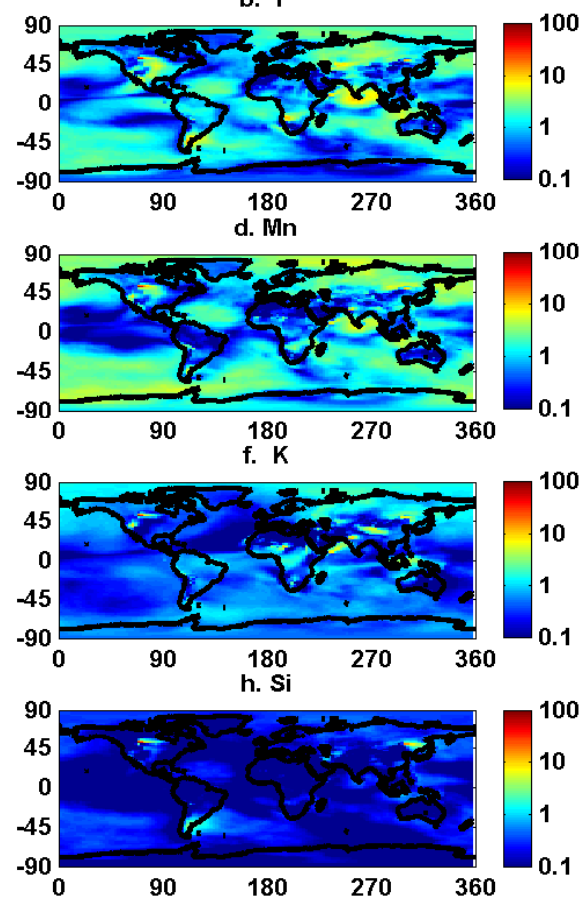

Figure 6. Ten-year monthly variability in mean of elemental percentages in atmospheric dust (mass \%): (a) $\mathrm{Mg}$, (b) $\mathrm{P}$, (c) $\mathrm{Ca}$, (d) $\mathrm{Mn}$, (e) $\mathrm{Fe}$, (f) $\mathrm{K}$, (g) $\mathrm{Al}$, (h) Si. Elemental monthly mean percentages are calculated using the monthly mean emission of each element divided by the monthly mean emission of dust.
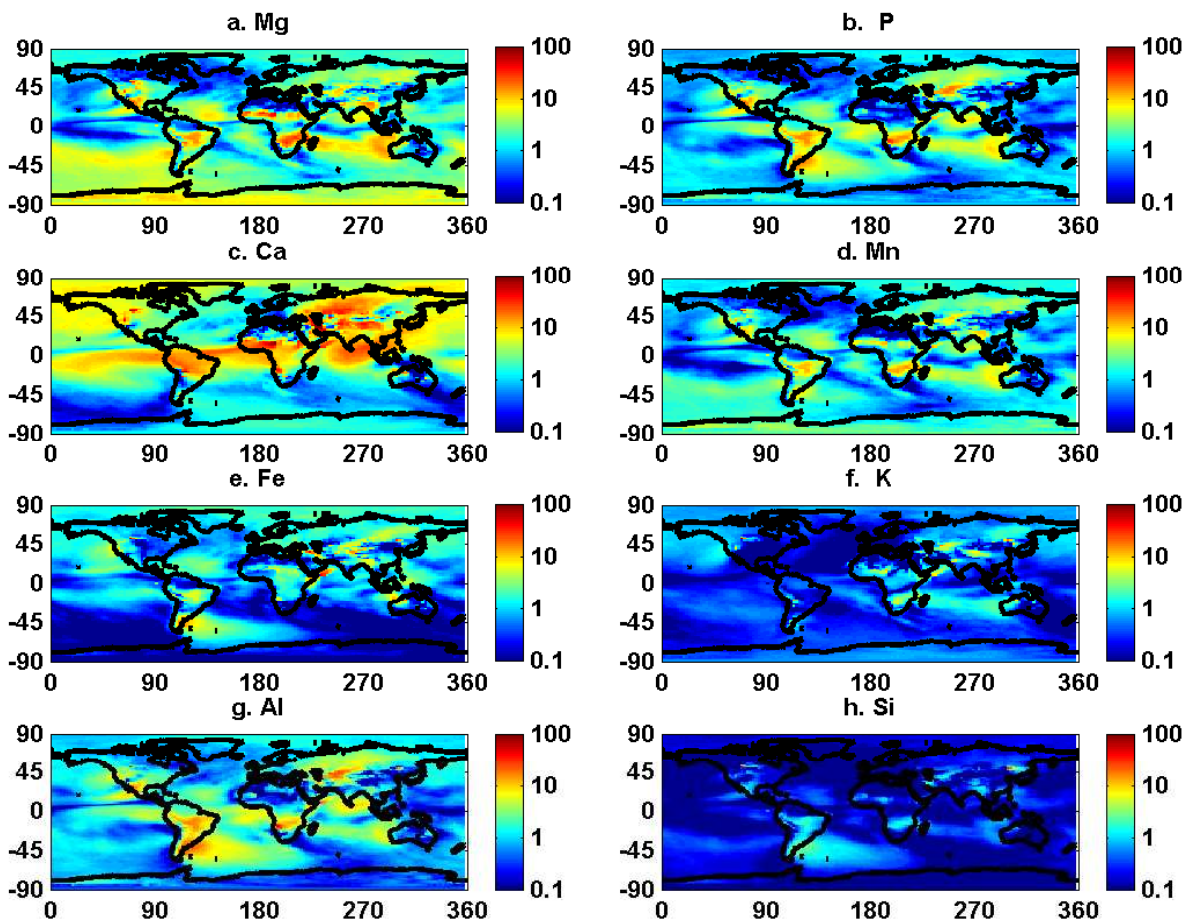

Figure 7. Ten-year monthly variability in mean of elemental percentages in dust deposition (mass \%): (a) $\mathrm{Mg}$, (b) $\mathrm{P}$, (c) Ca, (d) $\mathrm{Mn}$, (e) Fe, (f) $\mathrm{K}$, (g) $\mathrm{Al}$, (h) Si. Elemental monthly mean percentages are calculated using the monthly mean emission of each element divided by the monthly mean emission of dust. 
a. $\mathrm{Ca} / \mathrm{Al}$ in soil clay

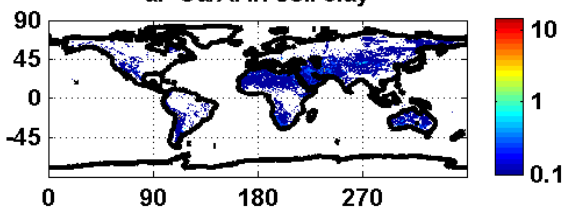

b. $\mathrm{Ca} / \mathrm{Al}$ in soil silt

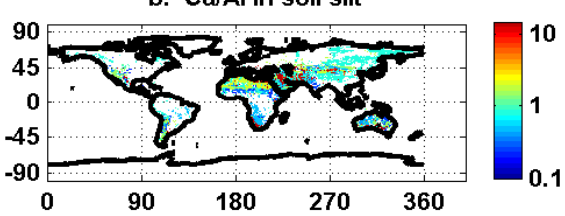

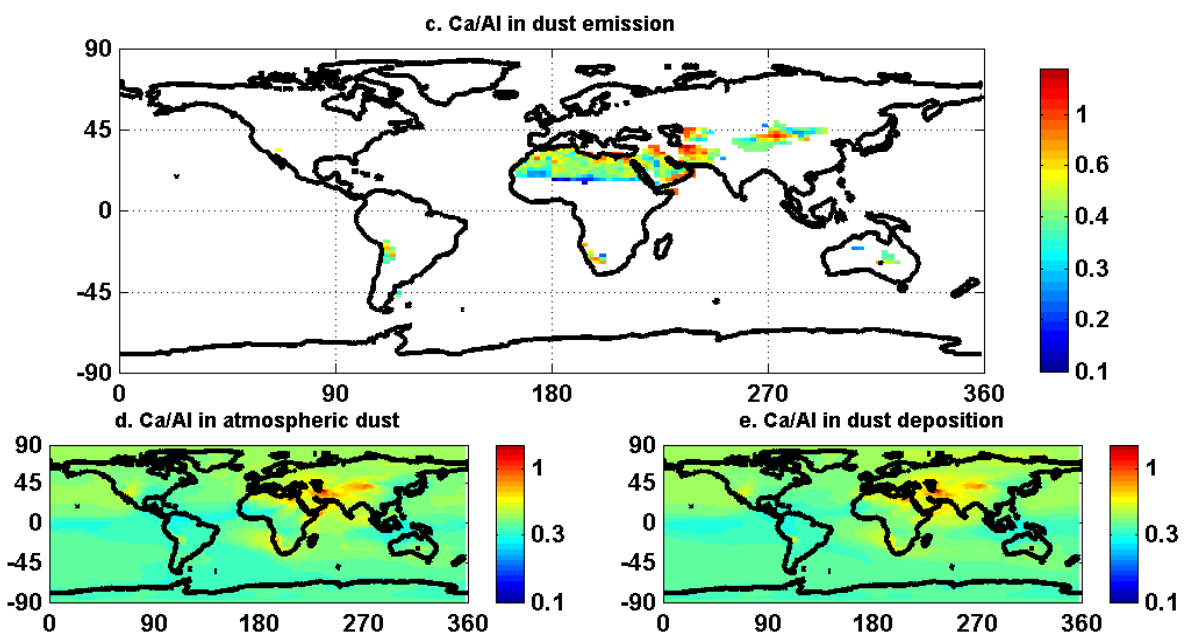

Figure 8. $\mathrm{Ca} / \mathrm{Al}$ in soil and 10-year-averaged $\mathrm{Ca} / \mathrm{Al}$ ratio in dust emission, concentration and deposition. Top two (a, b) refer to ratio in clay and silt desert soil, middle one (c) refers to ratio in dust emission, and bottom two (d, e) refer to ratio in dust concentration and deposition. Elemental annual mean percentages are calculated using the annual mean emission of each element divided by the annual mean emission of dust.
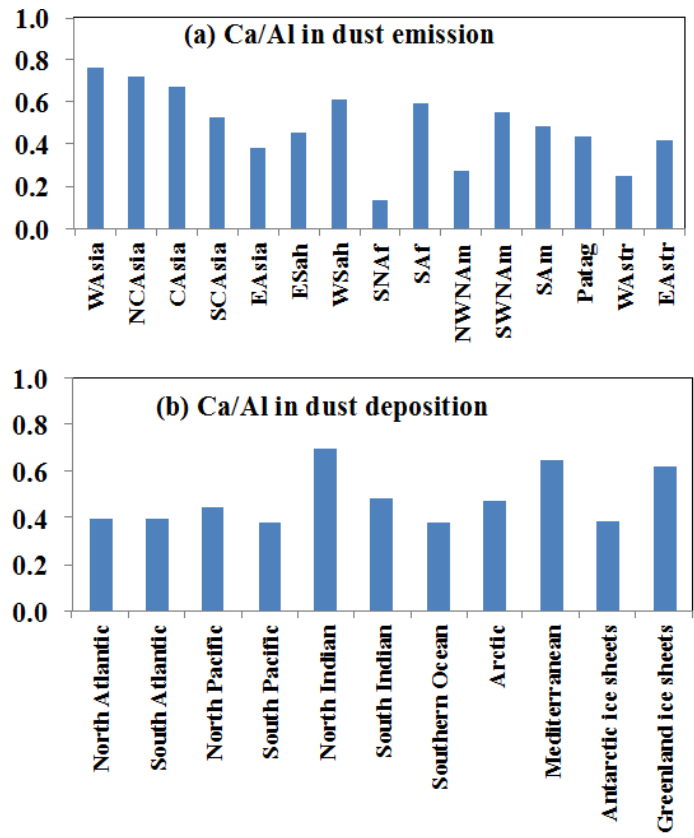

Figure 9. Ten-year averaged $\mathrm{Ca} / \mathrm{Al}$ ratio in (a) dust emission of source regions and (b) dust deposition into various ocean basins and glaciers. Elemental ratios are calculated using the annual mean emission of $\mathrm{Ca}$ divided by the annual mean emission of $\mathrm{Al}$. inally induced by the spatially variable elemental fraction. In the South Indian Ocean and the South Atlantic Ocean, the monthly variability is even higher and is attributed to the combined effect of variability in dust emissions, spatial concentration of elements, and dust transport patterns.

\subsection{Spatial Ca / Al distribution in soils and dust plumes}

Of specific interest is the $\mathrm{Ca} / \mathrm{Al}$ ratio in soil, atmospheric dust and deposited dust as this ratio may be indicative of specific source regions (Fig. 8). Of all considered ratios, the $\mathrm{Ca} / \mathrm{Al}$ ratio in soils shows the greatest variability in relation to the relevant desert region (e.g., Formenti et al. 2011). The $\mathrm{Ca} / \mathrm{Al}$ ratio ranges mainly between $0.1-1$ in clay fractions of soils and 0.5-5.0 in silt fractions of soils (Fig. 8a, b). The maximum $\mathrm{Ca} / \mathrm{Al}$ ratios reaches 160 times the global mean $\mathrm{Ca} / \mathrm{Al}$ ratio of 1.96 in the silt fraction of soils (Fig. 8b), much higher than those of other ratios such as $\mathrm{Fe}, \mathrm{K}$, and $\mathrm{Mn}$ to Al. Asian desert soils have higher $\mathrm{Ca} / \mathrm{Al}$ ratios, with values greater than 5 in West Asia and Central Asia. The Ca / Al ratio in dust emissions from Central Asia (1.0-1.6) are higher than in East Asia $(\sim 0.5)$, which is close to $\mathrm{Ca} / \mathrm{Al}$ ratios (1.0-1.7) derived from source profiles of Asian dust (Zhang et al., 1997, 2003), and also match the observed $\mathrm{Ca} / \mathrm{Al}$ ratios (0.7-1.3) during Asian dust events (Sun et al., 2004a, b; Shen et al., 2007). In addition, the $\mathrm{Ca} / \mathrm{Al}$ ratios in dust emissions 


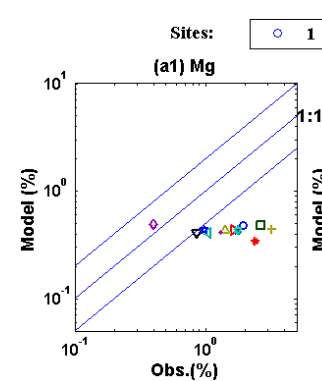

(a5) Fe
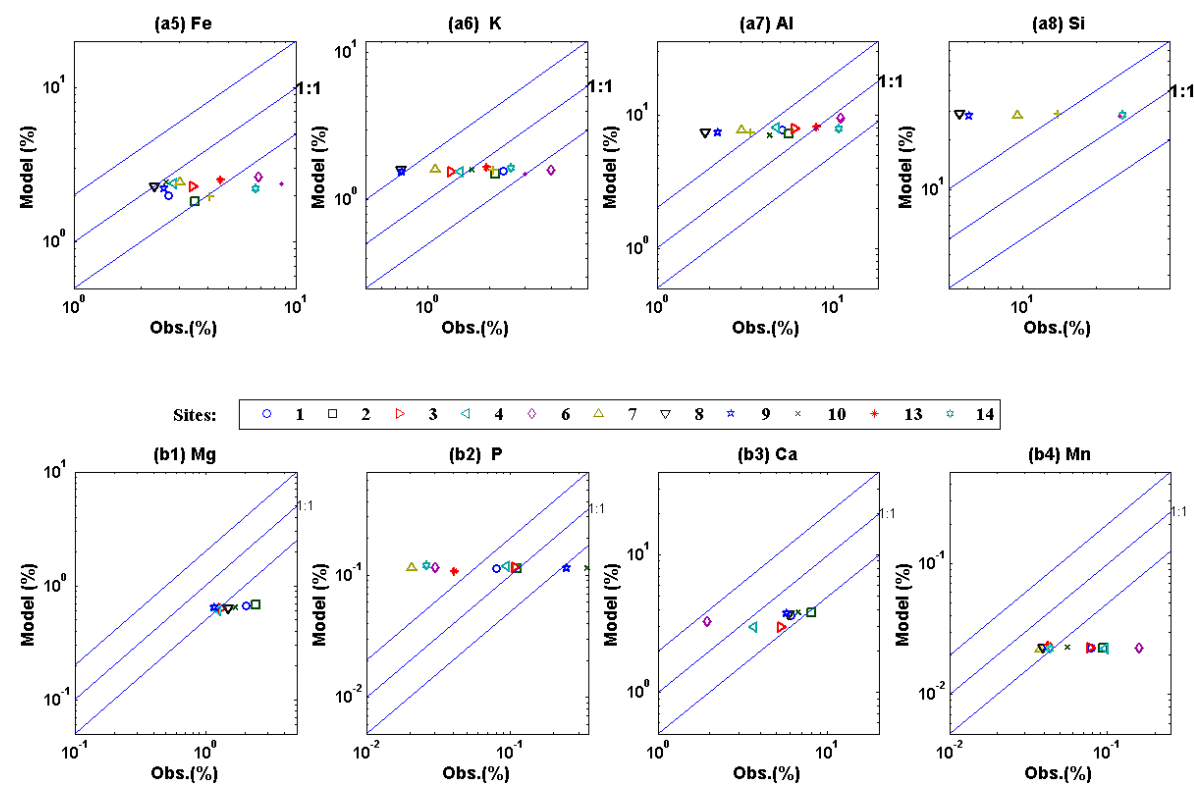

(b5) Fe
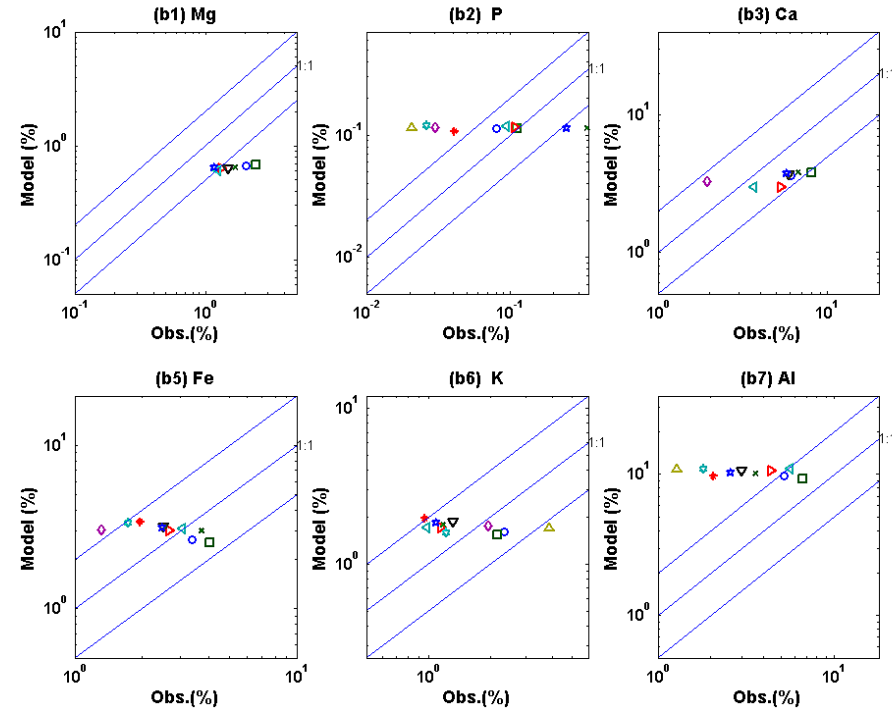

$\begin{array}{lll}13 & 14 \\ & \text { (b4) } \mathrm{Mn}\end{array}$

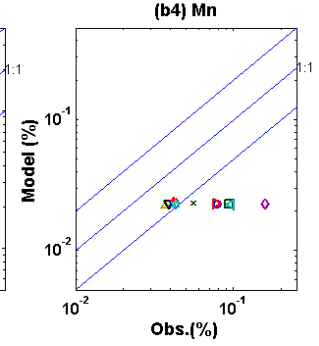

(b7) Al
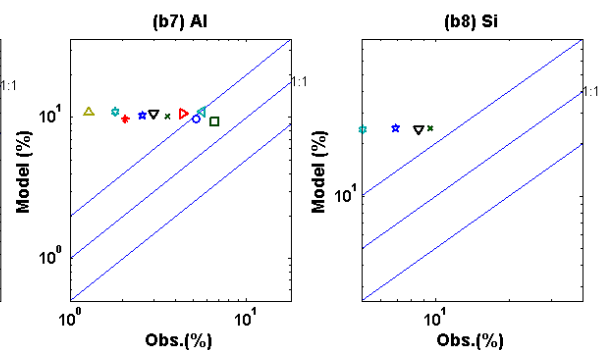

Figure 10. Comparison of observed and modeled mean fractions of elements at each site for (a) total suspended particulates (TSP) and (b) $\mathrm{PM}_{2.5}$. (1-Hetian, China; 2-Tazhong, China; 3-Yulin, China; 4-Duolun, China; 5-Shengsi, China; 6-Hanoi, Vietnam; 7-Manila, Philippines; 8-Balad, Iraq; 9-Baghdad, Iraq; 10-Taji, Iraq; 11-Eilat; 12-Cape Verde Atmospheric Observatory (CVAO); 13-Muswellbrook, Australia; 14-Richmond, Australia, 15-Tamanrasset, Algeria; 16-Banizoumbou, Niger; 17-Douz, Tunisia). Here we calculate the elemental fractions and average the fractions temporally for each site and compare to observations.

in North Africa are below 0.5, confirming the application of the $\mathrm{Ca} / \mathrm{Al}$ ratio of 0.3 (or 3.8 with $\mathrm{Al} / \mathrm{Ca}$ ) as an indicator of North African dust transport to the eastern United States (Perry et al., 1997). Ambient $\mathrm{PM}_{2.5}$ dust measured on the Canary Islands suggests a different ratio $(\mathrm{Ca} / \mathrm{Al}=1.004$; Engelbrecht et al., 2014). However, this ratio could be larger for $\mathrm{PM}_{10}$ or TSP. The high Ca / Al ratio (4.0-10.0) in a range of desert soils in some regions including South Africa, yields a Ca / Al ratio in dust emissions of 1.0, being much larger than those from North Africa. The modeled spatial pattern of $\mathrm{Ca} / \mathrm{Al}$ ratios in dust emissions from Asia and northwest Africa is consistent with the currently available dust pattern compiled by Formenti et al. (2011) but shows relatively lower values for the Central Asian desert region.

Despite experiencing mixing of airborne dust from various source regions and as a result of dust processing during transport, the $\mathrm{Ca} / \mathrm{Al}$ ratios still show spatial variations in global atmospheric dust and deposited dust. Relative to the $\mathrm{Ca} / \mathrm{Al}$ ratio in source regions (Fig. 8a, b), the $\mathrm{Ca} / \mathrm{Al}$ ratio in atmospheric dust over most of terrestrial Asia ranges mostly 

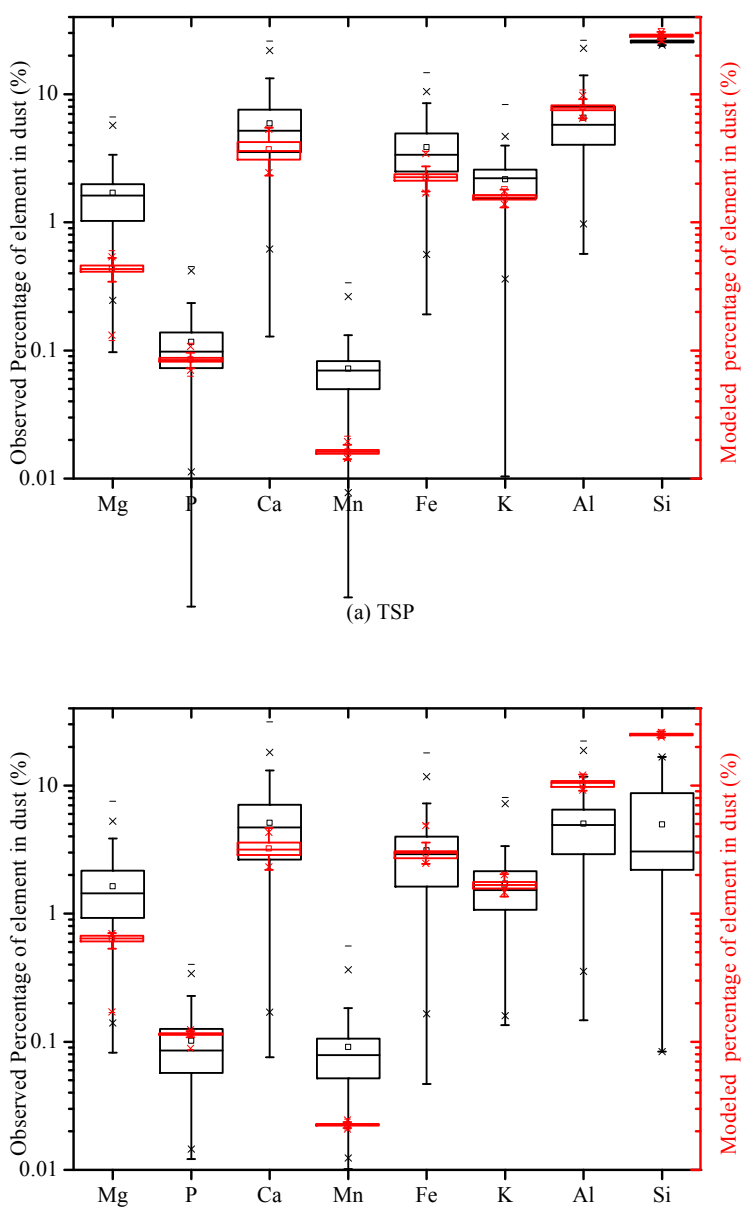

(b) $\mathrm{PM}_{2.5}$

Figure 11. Mean and quartile modeled and observational fractions of elements in (a) TSP and (b) $\mathrm{PM}_{2.5}$ for all sites together, the box line presents 25,50 and $75 \%$, individually. Here we calculate the elemental fractions and average the fractions temporally for each site and compare to observations.

between 0.5 and 0.8 , with a maximum of 1.8 . This is due to the spatial variability of $\mathrm{Ca} / \mathrm{Al}$ ratios in dust emissions (Fig. 9a) and despite the preferential gravitational settling during transport of the silt fraction which represents the highest $\mathrm{Ca} / \mathrm{Al}$ variability. The variability in $\mathrm{Ca} / \mathrm{Al}$ ratios in dust deposited into oceans and onto ice sheets are also shown in Fig. 9b. Near West Asia and western Sahara, higher Ca / Al ratios are noted and the North Indian Ocean and Mediterranean Sea have a $\mathrm{Ca} / \mathrm{Al}$ ratio above 0.65 in deposited dust. As the combined downwind region of Central Asia and East Asia, the North Pacific has a $\mathrm{Ca} / \mathrm{Al}$ ratio of around 0.5. The $\mathrm{Ca} / \mathrm{Al}$ ratio in dust deposited over the Atlantic ranges between 0.3 and 0.4 due to the influence of the southern North Africa desert region and eastern Sahara desert both with low ratios of $\mathrm{Ca} / \mathrm{Al}$. Since the soil data set has a high spatial resolution of $5 \mathrm{arcmin}$ (Fig. 8a, b), there is opportunity to in- crease the model grid resolution $\left(1.9 \times 2.5^{\circ}\right.$ in this study) to a finer resolution. It is expected that $\mathrm{Ca} / \mathrm{Al}$ ratios will show more spatial heterogeneity when a finer model resolution is used. We conclude that the $\mathrm{Ca} / \mathrm{Al}$ ratio can be used to identify different source areas and that the model can be used to support the observations.

\subsection{Model evaluation with observational data}

The averaged modeled fractions of elements in atmospheric dust at each site for the periods for which observations are available are comparable with observations for most of the sites (Fig. 10a, b). It is clear most scatter values of the model and observations are in the range of the $2: 1$ and $1: 2$ lines for most elements in TSP except for $\mathrm{Mg}, \mathrm{Mn}$ and Si. It shows the emission inventories based on mineralogy and elemental compositions are generally consistent with the available data. A large variability in the percentage of different elements is observed at the 17 observational sites for most elements, especially for $\mathrm{Ca}$ (Fig. 10). The fraction of Fe in the fine-mode particle $\left(\mathrm{PM}_{2.5}\right)$ is closer to the observational data than the TSP Fe fraction, implying that simulations of $\mathrm{Fe}$ in the clay soils is more accurate than in silt. Since there are only a few reported observations of $\mathrm{Si}$, this element is particularly difficult to verify. Based on averaged elemental fractions in TSP at 13 sites, the correlation coefficients $(R)$ between modeled and observed fractions range widely (Table 3). Ca and $\mathrm{Al} \mathrm{had}$ the highest correlations ( 0.75 and 0.72 , respectively). However, the correlation coefficients for $\mathrm{P}, \mathrm{Mn}$ and $\mathrm{K}$ were negative. For Fe, if we neglect the three sites in North Africa, the correlation coefficient increases from 0.29 to 0.50 ; in this area, the observational $\mathrm{Fe}$ fractions in TSP are high whereas the modeled ones are low (Figs. 10a, 5). The modeled elemental fractions in TSP are close to the observed data, with most ratios ranging between 0.7 and 1.6 (Table 3).

For this comparison (above mentioned), we calculate the elemental fractions and average the fractions temporally for each site and compare to observations but, alternatively, we could average the elemental concentrations and divide by the elemental dust concentrations instead, and this will make a difference in our interpretations. For example, taking site 2-Tazhong, the averaged fraction is $3.5 \%$ when we calculate the fractions of iron firstly and average those temporally. However, when we calculate the averaged iron mass and dust mass separately, their ratio is $2.3 \%$. For site 3-Yulin, the ratios are 3.6 and $3.1 \%$ for the first method and the second method, respectively. This difference may be due to dust storm events. For this comparison, we use the first method, as we think it is more suitable for our goal of simulating the percentage of each element correctly.

The averaged fractions of $\mathrm{Mg}$ and $\mathrm{Mn}$ in dust are underestimated by the model at all observational sites. It should be noted that there are some uncertainties when comparing elemental fractions. When the elemental concentration is divided by particle mass concentration to obtain the elemen- 

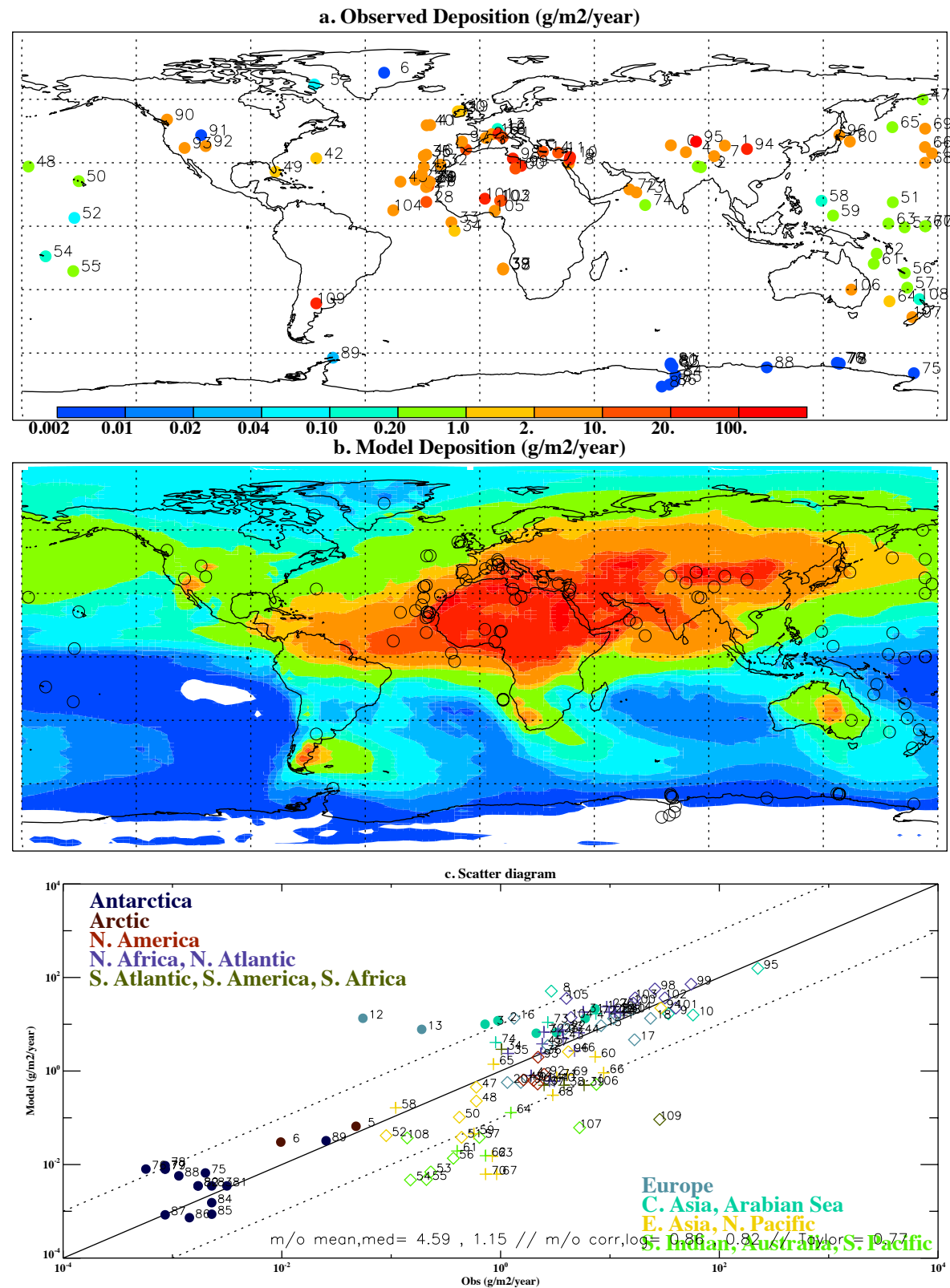

Figure 12. (a) Observational and (b) modeled dust deposition $\left(\mathrm{g} \mathrm{m}^{-3} \mathrm{yr}^{-1}\right)$. The scale is the same for both panels. (c) A scatterplot shows the comparison between the model and observations. The correlation coefficient between observations and model results is 0.86 .

tal fraction, the errors are amplified due to error propagation associated with the combination of the error on the particle mass and that of the element concentrations. Even though the available observational data are chosen from source sites or dust events in non-source regions, the contribution from other sources could be important, especially for fine-mode particles. The modeled fraction of $\mathrm{Mn}$ and $\mathrm{Al}$ in fine particles show a larger inconsistency than those in TSP when compared with observations. Some of the discrepancies may be because the model only includes particles up to $10 \mu \mathrm{m}$ in diameter, while the observations include larger particle fractions in TSPs. In South Asia, the elemental fractions in dust, with the exception of $\mathrm{Mn}$, are always much lower than at other sites, perhaps due to anthropogenic contributions to elemental particulate matter concentrations. In particular, many metals in insoluble forms in dust particles could be from other sources such as the refractories and steel industries, construction, biomass burning or volcanic emissions (Castillo et al., 2008; Gaudichet et al., 1995; Hinkley et al., 1999; Paris et al., 2010).

The daily elemental fractions across all times and sites where there is data show that while the mean of the model 

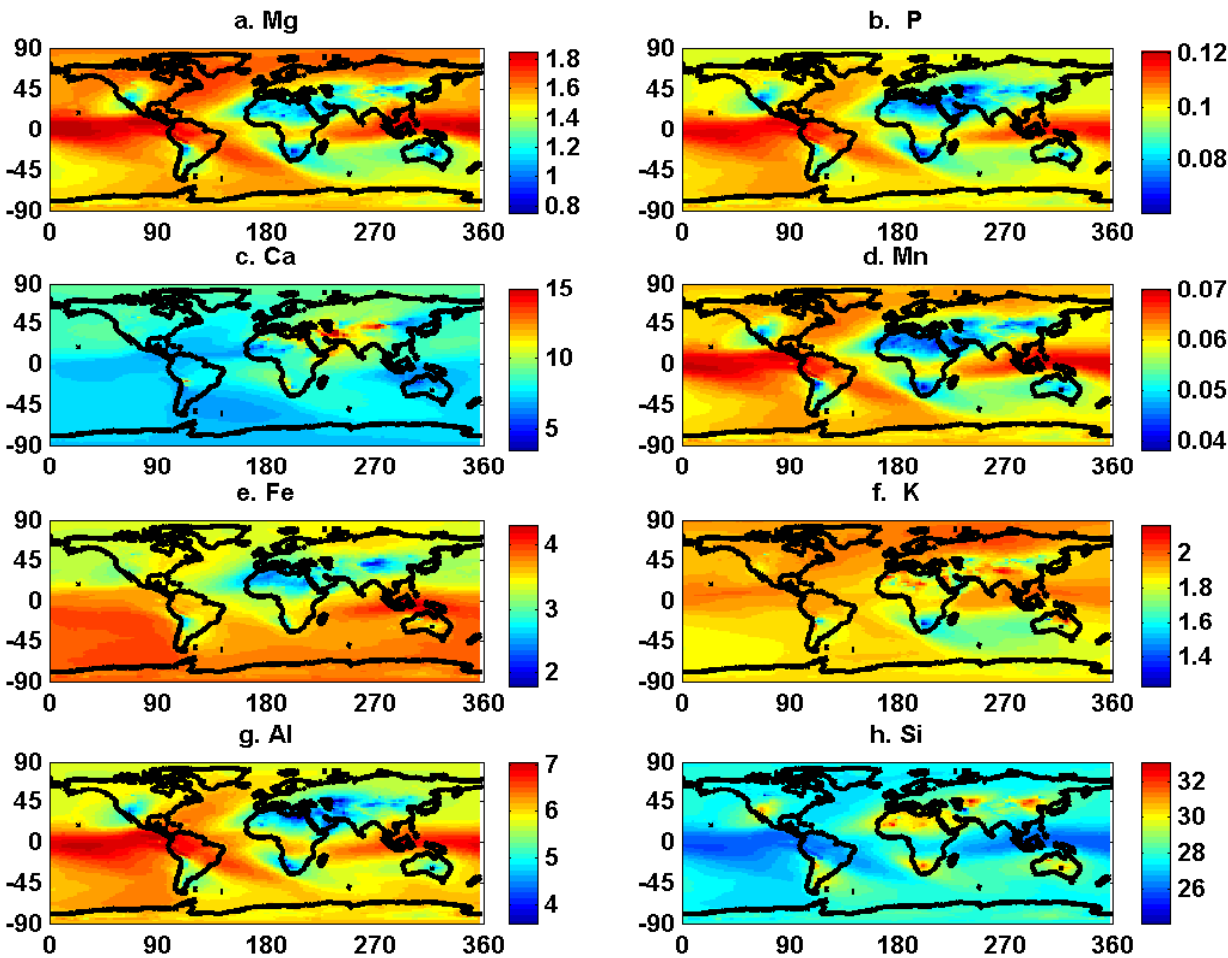

Figure 13. Percentages of elements in dust deposition (\%) after tuning. It is tuned based on original percentages of elements in dust deposition in Fig. S1 by timing the observed/modeled ratios listed in Table 3. Si did not change because there are not enough observational data available.
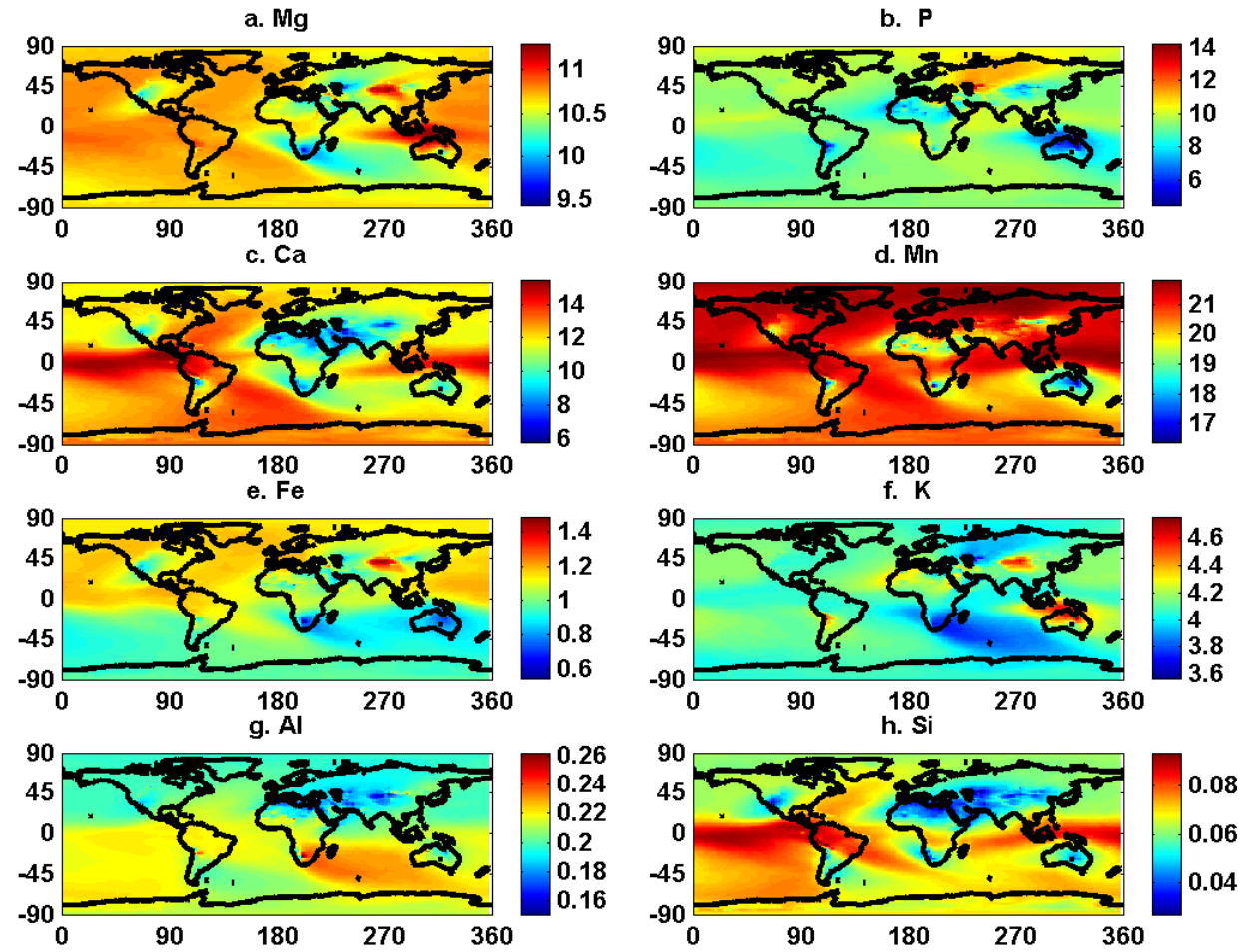

Figure 14. Fractional solubility of elements (soluble element / total element) in dust deposition (\%): (a) $\mathrm{Mg}$, (b) $\mathrm{P},(\mathbf{c}) \mathrm{Ca}$, (d) $\mathrm{Mn},(\mathbf{e}) \mathrm{Fe}$, (f) $\mathrm{K}$, (g) $\mathrm{Al}$, (h) $\mathrm{Si}$ 

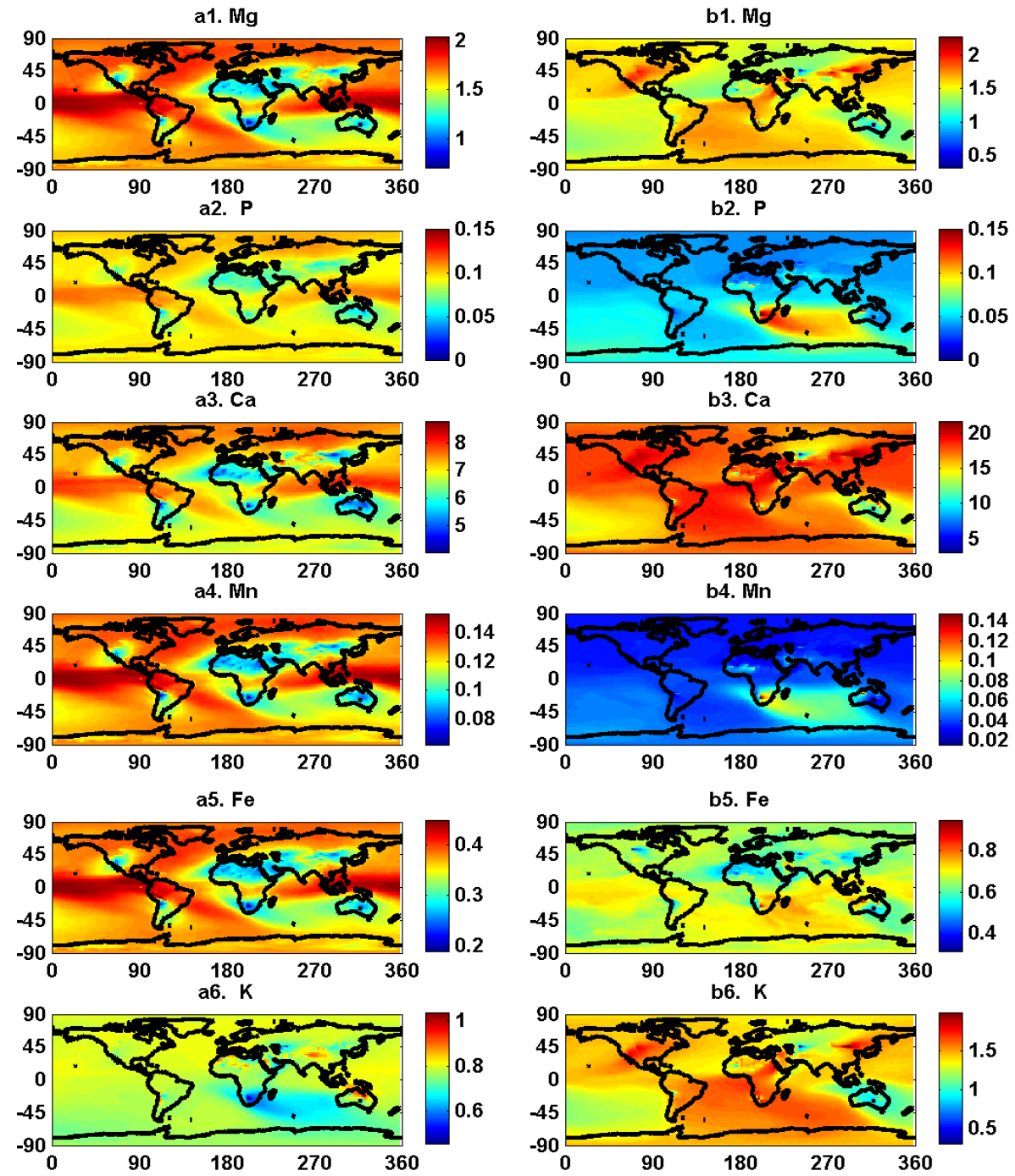

Figure 15. Percentages of soluble elements in total dust deposition using (a) Sol-1 and (b) Sol-2 (\%o). Sol-1 refers to the mineral method after tuning, Sol-2 refers to the Sillanpää method described in Sect. 2.

Table 4. Percentages (\%) of elements in dust deposition into different ocean basins and ice sheets*.

\begin{tabular}{lcccccccc}
\hline Ocean Basins/Glacier & $\mathrm{Mg}$ & $\mathrm{P}$ & $\mathrm{Ca}$ & $\mathrm{Mn}$ & $\mathrm{Fe}$ & $\mathrm{K}$ & $\mathrm{Al}$ & $\mathrm{Si}^{* *}$ \\
\hline North Atlantic & 1.43 & 0.10 & 5.36 & 0.06 & 3.05 & 1.89 & 5.96 & 28.32 \\
South Atlantic & 1.50 & 0.10 & 5.36 & 0.06 & 3.35 & 1.84 & 6.01 & 28.07 \\
North Pacific & 1.56 & 0.10 & 5.92 & 0.06 & 3.26 & 1.90 & 5.78 & 28.01 \\
South Pacific & 1.47 & 0.10 & 5.30 & 0.06 & 3.87 & 1.86 & 6.15 & 27.61 \\
North Indian & 1.38 & 0.08 & 7.90 & 0.05 & 3.13 & 1.81 & 4.95 & 28.29 \\
South Indian & 1.53 & 0.10 & 6.50 & 0.06 & 3.64 & 1.87 & 5.88 & 27.33 \\
Southern Ocean & 1.56 & 0.10 & 5.12 & 0.06 & 3.74 & 1.88 & 5.88 & 28.25 \\
Arctic & 1.60 & 0.10 & 6.23 & 0.06 & 3.31 & 1.96 & 5.76 & 27.76 \\
Mediterranean & 1.37 & 0.08 & 7.14 & 0.05 & 2.90 & 1.88 & 4.85 & 29.14 \\
Antarctic ice sheets & 1.50 & 0.10 & 4.90 & 0.06 & 3.54 & 1.82 & 5.55 & 29.17 \\
Greenland ice sheets & 1.50 & 0.09 & 7.49 & 0.06 & 2.82 & 1.89 & 5.24 & 28.00 \\
Averaged & 1.49 & 0.10 & 6.11 & 0.06 & 3.33 & 1.87 & 5.64 & 28.18 \\
\hline
\end{tabular}

* After timing tuned ratios (Table 3) except for Si. ** Non tuning. (For this table, annual mean deposition of each element is divided by the annual mean deposition of dust to obtain the percentage.) 
Table 5. Deposition of dust elements into different oceans and ice sheets*.

\begin{tabular}{|c|c|c|c|c|c|c|c|c|c|c|c|c|c|c|c|c|c|c|}
\hline \multirow[b]{2}{*}{ Ocean/ice sheet } & \multicolumn{3}{|c|}{$\operatorname{Mg}\left(\operatorname{Tg~yr}^{-1}\right)$} & \multicolumn{3}{|c|}{$\mathrm{P}\left(\mathrm{Gg} \mathrm{yr}^{-1}\right)$} & \multicolumn{3}{|c|}{$\mathrm{Ca}\left(\mathrm{Tg} \mathrm{yr}^{-1}\right)$} & \multicolumn{3}{|c|}{$\operatorname{Mn}\left(\mathrm{Gg} \mathrm{yr}^{-1}\right)$} & \multicolumn{3}{|c|}{$\mathrm{Fe}\left(\mathrm{Tg} \mathrm{yr}^{-1}\right)$} & \multicolumn{3}{|c|}{$\mathrm{K}\left(\mathrm{Tg} / \mathrm{yr}^{-1}\right)$} \\
\hline & Total & Sol-1 & Sol-2 & Total & Sol-1 & Sol-2 & Total & Sol-1 & Sol-2 & Total & Sol-1 & Sol-2 & Total & Sol-1 & Sol-2 & Total & Sol-1 & Sol-2 \\
\hline North Atlantic & 1.50 & 0.16 & 0.14 & 103.12 & 8.81 & 4.10 & 5.64 & 0.68 & 1.81 & 58.90 & 12.08 & 3.87 & 3.20 & 0.036 & 0.033 & 1.99 & 0.008 & 0.136 \\
\hline South Atlantic & 0.13 & 0.01 & 0.02 & 8.84 & 0.79 & 0.38 & 0.47 & 0.06 & 0.17 & 5.17 & 1.07 & 0.34 & 0.30 & 0.003 & 0.003 & 0.16 & 0.007 & 0.014 \\
\hline North Pacific & 0.28 & 0.03 & 0.03 & 17.47 & 1.66 & 0.65 & 1.06 & 0.13 & 0.33 & 10.58 & 2.25 & 0.58 & 0.58 & 0.007 & 0.006 & 0.34 & 0.014 & 0.025 \\
\hline South Pacific & 0.01 & 0.001 & 0.001 & 0.86 & 0.07 & 0.04 & 0.04 & 0.006 & 0.01 & 0.50 & 0.10 & 0.03 & 0.03 & 0.0003 & 0.000 & 0.02 & 0.0007 & 0.001 \\
\hline North Indian & 0.56 & 0.06 & 0.06 & 34.38 & 3.54 & 1.52 & 3.23 & 0.29 & 0.63 & 21.86 & 4.62 & 1.35 & 1.28 & 0.013 & 0.013 & 0.74 & 0.03 & 0.049 \\
\hline South Indian & 0.05 & 0.005 & 0.005 & 3.03 & 0.30 & 0.20 & 0.20 & 0.02 & 0.05 & 1.85 & 0.39 & 0.16 & 0.11 & 0.001 & 0.001 & 0.06 & 0.002 & 0.004 \\
\hline Southern Ocean & 0.002 & 0.0003 & 0.0003 & 0.15 & 0.01 & 0.01 & 0.01 & 0.001 & 0.003 & 0.09 & 0.02 & 0.01 & 0.01 & 0.0001 & 0.0001 & 0.00 & 0.0001 & 0.0002 \\
\hline Arctic Ocean & 0.02 & 0.002 & 0.0020 & 1.34 & 0.13 & 0.05 & 0.09 & 0.01 & 0.02 & 0.83 & 0.18 & 0.04 & 0.05 & 0.0005 & 0.0004 & 0.03 & 0.001 & 0.002 \\
\hline Mediterranean Sea & 0.18 & 0.02 & 0.02 & 10.66 & 1.07 & 0.36 & 0.92 & 0.09 & 0.22 & 6.76 & 1.42 & 0.36 & 0.37 & 0.004 & 0.004 & 0.24 & 0.011 & 0.017 \\
\hline Antarctic ice sheets & 0.001 & 0.0001 & 0.0001 & 0.08 & 0.007 & 0.003 & 0.00 & 0.001 & 0.002 & 0.05 & 0.01 & 0.003 & 0.00 & 0.00003 & 0.00003 & 0.00 & 0.0001 & 0.0001 \\
\hline Greenland ice sheets & 0.09 & 0.01 & 0.01 & 5.39 & 0.49 & 0.21 & 0.44 & 0.04 & 0.10 & 3.30 & 0.71 & 0.19 & 0.17 & 0.002 & 0.002 & 0.11 & 0.005 & 0.007 \\
\hline Total & 2.83 & 0.30 & 0.28 & 185.32 & 16.89 & 7.52 & 12.11 & 1.32 & 3.35 & 109.89 & 22.84 & 6.95 & 6.10 & 0.068 & 0.06 & 3.69 & 0.153 & 0.25 \\
\hline
\end{tabular}

was similar to the mean of the observations, there are some systematic differences (Fig. 11a, b). The modeled elemental fractions are not as variable as the observations. This could be due to several issues. First there is a greater variability in the soil mineralogy and elemental composition of minerals than those included in the model (we only include the average values). Secondly, the dust model could introduce systematic errors (through advection, although this is likely to be small, as discussed in the methods Sect. 2.1), or there could be some unaccounted anthropogenic particulate sources, modifying the dust aerosol. Also, inconsistencies in the collection methods and differences in aerosol sampling periods and times could yield the observed variations in elements as concluded by Lawrence and Neff (2009).

However, the ranges of the modeled fractions of $\mathrm{P}, \mathrm{Ca}, \mathrm{Fe}$, $\mathrm{K}$ and $\mathrm{Al}$ are close to the dominant range of the observational fractions (Fig. 11a, b). The measured fractions of elements in dust are reported to be $0.5-2.3 \%$ for $\mathrm{Mg}, 0.065-$ $0.2 \%$ for $\mathrm{P}, 1.0-10.2 \%$ for $\mathrm{Ca}, 0.028-0.124 \%$ for $\mathrm{Mn}, 1.3-$ 7.8\% for $\mathrm{Fe}, 1.2-4.6 \%$ for $\mathrm{K}, 3.7-12.7 \%$ for $\mathrm{Al}$, and 22.4 $35.7 \%$ for Si (Wilke et al., 1984; Reheis and Kihl, 1995; Stoorvogel et al., 1997; Zhang et al., 1998; Yadav and Rajamani, 2004; Goudie and Middleton, 2006; Moreno et al., 2006; Jeong, 2008; Lawrence and Neff, 2009; Formenti et al., 2008; Desboeufs et al., 2010). The modeled elemental fraction in dust for $\mathrm{P}, \mathrm{Ca}, \mathrm{Fe}, \mathrm{K}, \mathrm{Al}$ and $\mathrm{Si}$ were similar to observations. However, the modeled fractions of $\mathrm{Mg}$ and $\mathrm{Mn}$ are lower (3.4 and 3.5 times, respectively; Table 3 ) than the observed ones for samples used in this study or of the abovecited results. Underestimation of $\mathrm{Mg}$ and $\mathrm{Mn}$ could be due to a deficiency of minerals containing high concentrations of $\mathrm{Mg}$ and $\mathrm{Mn}$ in our model, as dolomite $(\mathrm{MgCO} 3)$ or palygorskite $\left((\mathrm{Mg}, \mathrm{Al})_{2} \mathrm{Si}_{4} \mathrm{O}_{10}(\mathrm{OH}) \times 4\left(\mathrm{H}_{2} \mathrm{O}\right)\right)$ are often identified in dust particles for $\mathrm{Mg}$ (e.g., Diaz-Hernandes et al., 2011; Kalderon et al., 2009). Moreover, it is known that the chemical composition of minerals could be variable according to the regional origin of minerals and possible impurities. For example, the $\mathrm{Mg}$ content in calcite ranges from 0 to $2.7 \%$ in the natural environment (Titschack et al., 2011). But in this study, the assumed fraction of $\mathrm{Mg}$ in calcite is zero because we took calcite as a pure mineral (see Table 1). So the underestimation of $\mathrm{Mg}$ in dust could be a propagation of errors in previous compositions in minerals considered in this study.

For reference we show the comparison of the modeled dust deposition versus observed deposition (Fig. 12). The modeled dust deposition flux agrees well with observations. The correlation coefficient between modeled and observed dust deposition is 0.86 . The median of model to observation ratio is 1.15 . Overall, the model has been tuned to represent dust deposition, concentration and aerosol optical depth (AOD; Albani, et al., 2014); however, the model has difficulty matching both deposition and concentration observations, similar to other models (Huneeus et al., 2011), suggesting more work on dust emission, transport and deposition processes is needed.

\subsection{Deposition of total and soluble dust elements over the ocean, land and ice sheets}

Comparisons between observations and the model simulations presented here suggest some bias in the model results (Fig. 11, Table 3); subsequently the model deposition values are adjusted to better match observed measurements by the tuning ratios (Table 3; Fig. 13). Of course, improving our elemental estimates in the source region would be preferred in future studies. From the observations, we have found a wide range in fractions of elements at individual sites and at the sites together; the ratio of the maximum and minimum in measured fractions could reach more than 700 for element $\mathrm{K}$, and more than 200 for $\mathrm{Ca}$ and $\mathrm{Mn}$. Because of the limited observations, we use a global tuning factor, based on the median elemental percentage, and contrast this result with our default modeling approach (Table 3). It is noted that both the median of observed $(3.10 \%)$ and modeled $(2.9 \%) \mathrm{Fe}$ was lower than $3.5 \%$, which was thought to be the fraction of $\mathrm{Fe}$ in dust (e.g., Luo et al., 2008; Mahowald et al., 2008).

This study suggests significant variability in the elemental fractions in dust deposition (Fig. 13, Table 4) and shows that the assumption that the fixed composition of dust being deposited over oceans is unlikely to be correct. Consistent 
with Mahowald et al. (2008), most dust deposition occurred downwind of dust generating regions bordering the North Atlantic, North Pacific and North Indian oceans. The Greenland ice sheet accounted for the dominant part of elemental deposition to ice sheets regions, which is equal to the total amount of elements deposited in the whole of the South Atlantic. Fe and $\mathrm{P}$ are key elements in the marine ecosystem, with $6.3 \mathrm{Tg}$ Fe and $184 \mathrm{Gg} \mathrm{P}$ added annually to all oceans and ice sheets (Table 5).

Also, the amounts of soluble dust element deposition are determined over different regions (see Sect. 2.1; Fig. 14). No atmospheric processing of natural dust or other sources of particles (e.g., anthropogenic sources) is included in this simulation. To better understand the uncertainties of soluble element deposition, estimates from two methods are used (Sect. 2.1) in simulating soluble elemental emission, transport and deposition. Fractional solubility of elements could not be estimated due to the lack of total element data from Method 2 (Sillanpää, 1982). Spatial variations in fractional solubility of elements are identified by Sol-1 (mineral method; Fig. 14). Fractional solubility of Ca increases with distance from source regions because its solubility is higher in clay than in silt (Table 1b). Fractional solubility of modeled $\mathrm{P}$ in deposition ranges from 5 to $15 \%$, with Saharan and Australian dust sources having solubilities averaging $\sim 10 \%$, consistent with Baker et al. (2006a, b). Previous observations suggest a fractional solubility for P of 7-100\% (e.g., Graham and Duce, 1982; Chen et al., 1985; Bergametti et al., 1992; Herut et al., 1999, 2002; Ridame and Guieu, 2002). Fractional solubility of $\mathrm{Fe}$ is $0.8-1.2 \%$ in regions (Fig. 14) where clay minerals such as illite play an important role (Journet et al., 2008) with a mean value of $1.17 \%$ of fractional Fe solubility (Table 1b). There is an obvious north-south gradient in the distribution of fractional solubility for $\mathrm{Fe}$ and $\mathrm{Al}$ but with opposing magnitude (Fig. 14). The fractional solubility could not be calculated using Sol-2 (Sillanpää method) since total elemental fractions in soil were not reported in Sillanpää (1982). Thus, the proportions of soluble Fe and K in total dust using two methods are compared with each other. This shows similar distribution patterns but the values are different (Fig. 15). The mineral method resulted in lower soluble $\mathrm{Ca}$ deposition and higher soluble $\mathrm{Mg}, \mathrm{P}$, and $\mathrm{Mn}$ (Fig. 15). Our results suggest significant differences in the spatial distribution of solubility depending on which data set is used to estimate soil solubility of elements. It should be noted that the solubility measurements by Sillanpää (1982) were performed at different $\mathrm{pH}$ values ( $\mathrm{pH}$ of 7 vs. 2) and media of extraction (acidified ultrapure waters vs. organic ligand solutions). It is known that $\mathrm{pH}$ and organic complexation greatly influence the fractional solubility, at least for Fe (e.g., Paris et al., 2010). Thus, that would explain the differences in elemental solubility that we computed for the dust. The soluble elemental deposition values over ocean basins and ice sheets are determined using two methods and are listed in Table 5. Annual inputs of soluble $\mathrm{Mg}, \mathrm{P}, \mathrm{Ca}, \mathrm{Mn}, \mathrm{Fe}$ and $\mathrm{K}$ from min- eral dust using method Sol-1 (Sol-2) were, respectively, 0.30 (0.28) Tg, 16.89 (7.52) Gg, 1.32 (3.35) Tg, 22.84 (6.95) Gg, $0.068(0.06) \mathrm{Tg}$, and $0.15(0.25) \mathrm{Tg}$ to oceans and ice sheets.

\section{Summary and conclusions}

A new technique combining soil and mineralogical data sets is introduced to estimate the global emission inventory of soil-associated elements $\mathrm{Mg}, \mathrm{P}, \mathrm{Ca}, \mathrm{Mn}, \mathrm{Fe}, \mathrm{K}, \mathrm{Al}$, and $\mathrm{Si}$. The spatial elemental dust emissions, transport and deposition are simulated using CESM from 2001 to 2010. Spatial variability of soil element fractions is characterized globally (Fig. 2) and shows that the use of a constant element fraction in dust across the globe is not consistent with existing observational data for $\mathrm{Ca}$ and $\mathrm{Al}$ (Figs. 10, 11). There are few observations for elemental distributions in source regions to verify these emission, concentration and deposition simulations but, for some elements ( $\mathrm{Ca}$ and $\mathrm{Al}$ ), the soil elemental distribution combined with the transported dust flux in the model better captures the percentage of chemical elements in dust concentrations observed (Figs. 10, 11). However, both $\mathrm{Mg}$ and Mn levels are underestimated by the model using the present mineral maps. The correlation of the percentage of elements at different sites is not statistically significant for several elements $(\mathrm{Mg}, \mathrm{Mn}, \mathrm{P}$ and $\mathrm{K})$, suggesting that improvements in the soil inventories or simulations is required, although these results could also be due to low numbers of observations. The observations and model results suggest the elemental fractions in dust varied globally and between different dust production regions, especially for $\mathrm{Ca}$ with values from 1 to $30 \%$. The ratio of $\mathrm{Ca} / \mathrm{Al}$, ranged between 0.1 and 5.0 and is confirmed as an indicator of dust source regions (Zhang et al., 1997, 2003; Sun et al., 2004a, b; Shen et al., 2007). For Fe in TSP, the median of the modeled fraction is $2.90 \%$, less than the commonly assumed $3.5 \%$ Fe used in dust models (e.g., Luo et al., 2008; Mahowald et al., 2008).

The seasonal variability of emission, concentration and deposition of most elements is simulated in the model. Also, different soluble elemental data sets show that the fractional solubility of elements varies spatially. Mineral dust element deposition fluxes into ocean basins are updated using a variable fractional elemental inventory and could have potentially important impacts on evaluating their biogeochemical effects. This study shows that soil emission inventories do a fairly good job at predicting dust elemental concentrations during dust events, except for $\mathrm{Mg}$ and $\mathrm{Mn}$. However, the high spatial heterogeneity in elemental distributions is not captured in the model. Several sources of uncertainties exist in the model projections, the largest of which is likely to be from the assumptions in the soil mappings of soil types to minerals to elemental distributions. In the future, these dust emission inventories can be combined with anthropogenic elemental inventories to further improve our understanding of elemental deposition to the oceans. 


\section{The Supplement related to this article is available online at doi:10.5194/bg-12-5771-2015-supplement.}

Acknowledgements. We would like to thank the US Department of Defense (DOD) for sharing chemical data from their Enhanced Particulate Matter Surveillance Program (EPMSP) and the anonymous reviewers for helpful comments. We acknowledge the support of NSF grants 0932946 and 1137716 and DOE-SC0006735. Simulations were conducted on the NSF National Center for Atmospheric Research supercomputers.

Edited by: G. Herndl

\section{References}

Albani, S., Mahowald, N. M., Perry, A. T., Scanza, R. A., Zender, C. S., Heavens, N. G., Maggi, V., Kok, J. F., and OttoBliesner, B. L.: Improved dust representation in the Community Atmosphere Model, J. Adv. Model. Earth Syst., 6, 541-570, doi:10.1002/2013MS000279, 2014.

Baker, A. R. and Croot, P. L.:. Atmospheric and marine controls on aerosol iron solubility in seawater, Mar. Chem., 120, 4-13, 2010.

Baker, A. R., Kelly, S. D., Biswas, K. F., Witt, M., and Jickells, T. D.: Atmospheric deposition of nutrients to the Atlantic Ocean, Geophys. Res. Lett., 30, 2296, doi:10.1029/2003GL018518, 2003.

Baker, A. R., French, M., and Linge, K. L.: Trends in aerosol nutrient solubility along a west-east transect of the Saharan dust plume, Geophys. Res. Lett., 33, L07805, doi:10.1029/2005GL024764, 2006a.

Baker, A. R., Jickells, T. D., Witt, M., and Linge, K. L.: Trends in the solubility of iron, aluminum, manganese and phosphorus collected over the Atlantic Ocean, Mar. Chem., 98, 43-58, doi:10.1016/j.marchem.2005.06.004, 2006b.

Bergametti, G., Gomes, L., Coudé-Gaussen, G., Rognon, P., and Le Coustumer, M.: African dust observed over Canary Islands: Source-regions identification and transport pattern for some summer situations, J. Geophys. Res., 12, 14855-14864, doi:10.1029/JD094iD12p14855, 1989.

Bergametti, G., Remoudaki, E., Losno, R., Steiner, E., Chatenet, B., and Buat-Menard, P.: Source, transport and deposition of atmospheric phosphorus over the northwestern Mediterranean, J. Atmos. Chem., 14, 501-513, doi:10.1007/BF00115254, 1992.

Boyd, P., Wong, C., Merril, J., Whitney, F., Snow, J., Harrison, P., and Gower, J.: Atmospheric iron supply and enhanced vertical carbon flux in the NE subsartic Pacific: is there a connection?, Global Biogeochem. Cy., 12, 429-441, 1998.

Buck, C., Landing, W. M., Resing, J. A., and Lebon, G.: Aerosol iron and alumninum solubility in the northwest Pacific Ocean: results from the 2002 IOC Cruise, Geochem. Geophy. Geosy., 7, Q04M07, doi:10.1029/2005GC000977, 2006.

Capone, D. G., Zehr, J. P., Paerl, H. W., Bergman, B., and Carpenter, E. J.: Trichodesmium, a globally significant marine cyanobacterium, Science, 276, 1221-1229, 1997.
Carpenter, L. J., Fleming, Z. L., Read, K. A., Lee, J. D., Moller, S. J., Hopkins, J. R., Purvis, R. M., Lewis, A. C., Müller, K., Heinold, B., Herrmann ,H., Fomba, K. W., Pinxteren, D. v., Müller, C., Tegen, I., Wiedensohler, A., Müller, T., N. Niedermeier, Achterberg, E. P., Patey, M. D., Kozlova, E. A., Heimann, M., Heard, D. E., Plane, J. M. C., Mahajan, A., Oetjen, H., Ingham, T. Stone, D., Whalley, L. K., Evans, M. J., Pilling, M. J., Leigh, R. J., Monks, P. S., Karunaharan, A., Vaughan, S., Arnold, S. R., Tschritter, J., Pöhler, D., Frieß, U., Holla, R., Mendes, L. M., Lopez, H., Faria, B., Manning, A. J., and Wallace, D. W. R.: Seasonal characteristics of tropical marine boundary layer air measured at the Cape Verde Atmospheric Observatory, J. Atmos. Chem., 67, 87-140, doi:10.1007/s10874-011-9206-1, 2010.

Castillo, S., Moreno, T., Querol, X., Alastuey, A., Cuevas, E., Herrmann, L., Monkaila, M., and Gibbons, W.: Trace element variation in size-fractionated African desert dusts, J. Arid Environ., 72, 1034-1045, 2008.

Chen, L., Arimoto R., and Duce R. A.: The sources and forms of phosphorus in marine aerosol particles and rain from Northern New Zealand, Atmos. Environ., 19, 779-787, 1985.

Chen, Y. and Siefert, R.: Sesaonal and spatial distributions and dry deposition fluxes of atmospheric total and labile iron over the tropical and subtropical North Atlantic Ocean, J. Geophys. Res., 109, D09305, doi:10.1029/2003JD003958, 2004.

Chen, Y., Paytan, A., Chase, Z., Measures, C., Beck, A. J., SañudoWilhelmy, S. A., and Post, A. F.: Sources and fluxes of atmospheric trace elements to the Gulf of Aqaba, Red Sea, J. Geophys. Res., 113, D05306, doi:10.1029/2007JD009110, 2008.

Christian, J. R.: Advection in plankton models with variable elemental ratios, Ocean Dynam., 57, 63-71, doi:10.1007/s10236006-0097-7, 2007.

Claquin, T., Schulz, M., and Balkanski, Y. J.: Modeling the mineralogy of atmospheric dust sources, J. Geophys. Res., 104, 22243 22256, 1999

Cohen, D. D., Stelcer, E., Hawas, O., and Garton, D.: IBA methods for characterisation of fine particulate atmospheric pollution: a local, regional and global research problem, Nucl. Instrum. Meth. B, 219, 145-152, 2004.

Cohen, D. D., Stelcer, E., Garton, D., and Crawford, J.: Fine particle characterization, source apportionment and long range dust transport into the Sydney Basin: a long term study between 1998 and 2009, Atmos. Pollut. Res., 2, 182-189, 2011.

Desboeufs, K., Journet, E., Rajot, J.-L., Chevaillier, S., Triquet, S., Formenti, P., and Zakou, A.: Chemistry of rain events in West Africa: evidence of dust and biogenic influence in convective systems, Atmos. Chem. Phys., 10, 9283-9293, doi:10.5194/acp10-9283-2010, 2010.

Díaz-Hernández, J. L., Martín-Ramos, J. D., and López-Galindo, A.: Quantitative analysis of mineral phases in atmospheric dust deposited in the south-eastern Iberian Peninsula, Atmos. Environ., 45, 3015-3024, doi:10.1016/j.atmosenv.2011.03.024, 2011.

Duce, R. A. and Tindale, N. W.: Atmospheric transport of iron and its deposition in the ocean, Limnol. Oceanogr., 36, 1715-1726, 1991.

Engelbrecht, J. P., McDonald, E. V., Gillies, J. A., Jayanty, R. K. M., Casuccio, G., and Gertler, A. W.: Characterizing mineral dusts and other aerosols from the Middle East - Part 1: Ambient sampling, Inhal. Toxicol., 21, 297-326, 2009. 
Engelbrecht, J. P., Menendez, I., and Derbyshire, E.: Sources of PM2.5 impacting on Gran5 Canaria, Spain, Catena, 117, 119132, doi:10.1016/j.catena.2013.06.017, 2014.

FAO-Unesco: The Digitized Soil Map of the World and Derived Soil Properties, (version 3.5), Land and Water Digital Media Series 1, FAO, Rome, 1995.

Formenti, P., Rajot, J. L., Desboeufs, K., Caquineau, S., Chevaillier, S., Nava, S., Gaudichet, A., Journet, E., Triquet, S., Alfaro, S., Chiari, M., Haywood, J., Coe, H., and Highwood, E.: Regional variability of the composition of mineral dust from western Africa: results from the AMMA SOP0/DABEX and DODO field campaigns, J. Geophys. Res., 113, D00C13, doi:10.1029/2008JD009903, 2008.

Formenti, P., Schütz, L., Balkanski, Y., Desboeufs, K., Ebert, M., Kandler, K., Petzold, A., Scheuvens, D., Weinbruch, S., and Zhang, D.: Recent progress in understanding physical and chemical properties of African and Asian mineral dust, Atmos. Chem. Phys., 11, 8231-8256, doi:10.5194/acp-11-8231-2011, 2011.

Fung, I., Meyn, S. K., Tegen, I., Doney, S., John, J., and Bishop, J.: Iron supply and demand in the upper ocean, Global Biogeochem. Cy., 14, 281-295, 2000.

Gaudichet, A., Echalar, F., Chatenet, B., Quisefit, J. P., Malingre, G., Cachier, H., Buatmenard, P., Artaxo, P., and Maenhaut, W.: Trace elements in tropical African savanna biomass burning aerosols, J. Atmos. Chem., 22, 19-39, 1995.

Gold, C. M., Cavell, P. A., and Smith, D. G. W.: Clay minerals in mixtures: sample preparation, analysis, and statistical interpretation, Clay. Clay. Miner., 3, 191-199, 1983.

Goudie, A. S. and Middleton, N. J.: Desert Dust in the Global System, Springer, Berlin, 287 pp., 2006.

Graham, W. F. and Duce, R. A.: The atmospheric transport of phosphorus to the western North Atlantic, Atmos. Environ., 16, 10891097, doi:10.1016/0004-6981(82)90198-6, 1982.

Guieu, C., Bonnet, S., Wagener, T., and Loye-Pilot, M.-D.: Biomass burning as a source of dissolved iron to the open ocean?, Geophys. Res. Lett., 22, L19608, doi:10.1029/2005GL022962, 2005.

Guo, L., Chen, Y., Wang, F. J., Meng, X., Xu, Z. F., and Zhuang, G.: Effects of Asian dust on the atmospheric input of trace elements to the East China Sea, Mar. Chem., 163, 19-27, doi:10.1016/j.marchem.2014.04.003, 2014.

Han, L., Zhuang, G., Sun, Y., and Wang, Z.: Local and non-local sources of airborne particulate pollution at Beijing, Science in China Ser. B Chemistry, 48, 253-264, 2005 (in Chinese).

Hand, J. L., Mahowald, N. M., Chen, Y., Siefert, R. L., Luo, C., Subramaniam, A., and Fung, I.: Estimates of atmosphericprocessed soluble iron from observations and a global mineral aerosol model: Biogeochemical implications, J. Geophys. Res., 109, D17205, doi:10.1029/2004JD004574, 2004.

Herut, B., Krom, M., Pan, G., and Mortimer, R.: Atmospheric input of nitrogen and phosphorus to the southeast Mediterranean: sources, fluxes and possible impact, Limnol. Oceanogr., 44, 1683-1692, 1999.

Herut, B., Collier, R., and Krom, M.: The role of dust in supplying nitrogen and phosphorus to the southeast Mediterranean, Limnol. Oceanogr., 47, 870-878, 2002.

Herut, B., Zohary, T., Krom, M. D., Mantoura, R. F. C., Pitta, V., Psarra, S., Rassoulzadegan, F., Tanaka, T., and Thingstad, F. T.: Response of east Mediterranean surface water to Saharan dust: on-board microcosm experiment and field observations, Deep-
Sea Res. Pt. II, 52, 3024-3040, doi:10.1016/j.dsr2.2005.09.003, 2005.

Hinkley, T. K., Lamothe, P. J., Wilson, S. A., Finnegan, D. L., and Gerlach, T. M.: Metal emissions from Kilauea, and a suggested revision of the estimated worldwide metal output by quiescent degassing of volcanoes, Earth Planet. Sc. Lett., 170, 315-325, 1999.

Huneeus, N., Schulz, M., Balkanski, Y., Griesfeller, J., Prospero, J., Kinne, S., Bauer, S., Boucher, O., Chin, M., Dentener, F., Diehl, T., Easter, R., Fillmore, D., Ghan, S., Ginoux, P., Grini, A., Horowitz, L., Koch, D., Krol, M. C., Landing, W., Liu, X., Mahowald, N., Miller, R., Morcrette, J.-J., Myhre, G., Penner, J., Perlwitz, J., Stier, P., Takemura, T., and Zender, C. S.: Global dust model intercomparison in AeroCom phase I, Atmos. Chem. Phys., 11, 7781-7816, doi:10.5194/acp-11-7781-2011, 2011.

Jeong, G. Y.: Bulk and single-particle mineralogy of Asian dust and a comparison with its source soils, J. Geophys. Res., 113, D02208, doi:10.1029/2007jd008606, 2008.

Jickells, T., An, Z., Andersen, K., Baker, A., Bergametti, G., Brooks, N., Cao, J., Boyd, P., Duce, R., Hunter, K., Kawahata, H., Kubilay, N., LaRoche, J., Liss, P., Mahowald, N., Prospero, J., Ridgwell, A., Tegen, I., and Torres, R.: Global iron connections between dust, ocean biogeochemistry and climate, Science, 308, 67-71, 2005.

Journet, E., Desboeufs, K. V., Caquineau, S., and Colin, J.-L.: Mineralogy as a critical factor of dust iron solubility, Geophys. Res. Lett., 35, L07805, doi:10.1029/2007g1031589, 2008.

Journet, E., Balkanski, Y., and Harrison, S. P.: A new data set of soil mineralogy for dust-cycle modeling, Atmos. Chem. Phys., 14, 3801-3816, doi:10.5194/acp-14-3801-2014, 2014.

Kalderon-Asael, B., Erel, Y., Sandler, A., and Dayan, U.: Mineralogical and chemical characterization of suspended atmospheric particles over the east Mediterranean based on synoptic-scale circulation patterns, Atmos. Environ., 43, 3963-3970, 2009.

Kandler, K., Benker, N., Bundke, U., Cuevas, E., Ebert, M., Knippertz, P., Rodríguez, S., Schütz, L., and Weinbruch, S.: Chemical composition and complex refractive index of Saharan mineral dust at Izaña, Tenerife (Spain) derived by electron microscopy, Atmos. Environ., 41, 8058-8074, 2007.

Kok, J. F.: A scaling theory for the size distribution of emitted dust aerosols suggests climate models underestimate the size of the global dust cycle, P. Natl. Acad. Sci. USA, 108, 1016-021, 2011.

Kreutz, K. J. and Sholkovitz, E. R.: Major element, rare earth element, and sulfur isotopic composition of a high-elevation firncore: sources and transport of mineral dust in central Asia, Geochem. Geophy. Geosy., 1, 1048-1071, 2000.

Lam, P. and Bishop, J.: The continental margin is a key sources of iron to the North Pacific Ocean, Geophys. Res. Lett., 35, L07608, doi:10.1029/2008GL033294, 2008.

Lawrence, C. R. and Neff, J. C.: The physical and chemical flux of eolian dust across the landscape: a synthesis of observations and an evaluation of spatial patterns, Chem. Geol., 267, 46-63, doi:10.1016/j.chemgeo.2009.02.005, 2009.

Li, G., Chen, J., Chen, Y., Yang, J., Ji, J., and Liu, L.: Dolomite as a tracer for the source regions of Asian dust, J. Geophys. Res., 112, D17201, doi:10.1029/2007jd008676, 2007.

Lin, S.-J. and Rood, R. B.: An explicit flux-form semi-Lagrangian shallow-water model on the sphere, Q. J. Roy. Meteor. Soc., 123, 2477-2498,1997. 
Luo, C., Mahowald, N., Bond, T., Chuang, P. Y., Artaxo, P., Siefert, R., Chen, Y., and Schauer, J.: Combustion irondistribution and deposition, Global Biogeochem. Cy., 22, GB1012, doi:10.1029/2007GB002964, 2008.

Mahowald, N., Baker, A., Bergametti, G., Brooks, N., Duce, R., Jickells, T., Kubilay, N., Prospero, J., and Tegen, I.: Atmospheric global dust cycle and iron inputs to the ocean, Global Biogeochem. Cy., 19, GB4025, doi:10.1029/2004GB002402, 2005.

Mahowald, N., Muhs, D. R., Levis, S., Rasch, P. J., Yoshioka, M., Zender, C. S., and Luo, C.: Change in atmospheric mineral aerosols in response to climate: last glacial period, preindustrial, modern, and doubled carbon dioxide climates, J. Geophys. Res.Atmos., 111, D10202, doi:10.1029/2005JD006653, 2006.

Mahowald, N., Jickells, T. D., Baker, A. R., Artaxo, P., BenitezNelson, C. R., Bergametti, G., Bond, T. C., Chen, Y., Cohen, D. D., Herut, B., Kubilay, N., Losno, R., Luo, C., Maenhaut, W., McGee, K. A., Okin, G. S., Siefert, R. L., and Tsukuda, S.: Global distribution of atmospheric phosphorus sources, concentrations and deposition rates, and anthropogenic impacts, Global Biogeochem. Cy., 22, GB4026, doi:10.1029/2008GB003240, 2008.

Marino, F., Maggi, V., Delmonte, B., Ghermandi, G., and Petit, J. R.: Elemental composition ( $\mathrm{Si}, \mathrm{Fe}, \mathrm{Ti}$ ) of atmosphericdust over the last $220 \mathrm{kyr}$ from the EPICA ice core (Dome C, Antarctica), Ann. Glaciol., 39, 110-118, doi:10.3189/172756404781813862, 2004.

Marteel, A., Gaspari, V., Boutron, C. F., Barbante, C., Gabrielli, P., Cescon, P., Ferrari, C., Dommergue, A., Rosman, K., Hong, S., and Hur, S.: Climate-related variations in crustal trace elements in Dome C (East Antarctica) ice during the past $672 \mathrm{kyr}$, Climatic Change, 92, 191-211, 2009.

Martin, J. H., Gordon, R. M., and Fitzwater, S. E.: The case for iron, Limnol. Oceanogr., 36, 1793-1802, 1991.

Measures, C. and Vink, S.: On the use of dissolved aluminum in surface waters to estimate dust deposition to the ocean, Global Biogeochem. Cy., 14, 317-327, 2000.

Mermut, A. R. and Cano, A. F.: Baseline studies of the clay minerals society source clays: chemical analyses of major elements, Clay. Clay. Miner., 49, 381-386, 2001.

Mills, M. M., Ridame, C., Davey, M., LaRoche, J., and Geider, R.: Iron and phosphorus co-limit nitrogen fixation in the eastern tropical North Atlantic, Nature, 429, 292-294, 2004.

Moore, J. K. and Braucher, O.: Sedimentary and mineral dust sources of dissolved iron to the world ocean, Biogeosciences, 5, 631-656, doi:10.5194/bg-5-631-2008, 2008.

Morel, F. M. M., Milligan, A. J., and Saito, M. A.: Marine bioinorganic chemistry: the role of trace metals in the oceanic cycles of major nutrients, in: Treatise on Geochemistry, Vol. 6, Elsevier, Pergamon, Oxford, 113-143, ISBN 0-08-043751-6, 2003.

Moreno, T., Querol, X., Castillo, S., Alastuey, A., Cuevas, E., Herrmann, L., Mounkaila, M., Elvira, J., and Gibbons, W.: Geochemical variations in aeolian mineral particles from the SaharaSahel dust corridor, Chemosphere, 65, 261-270, 2006.

Nickovic, S., Vukovic, A., Vujadinovic, M., Djurdjevic, V., and Pejanovic, G.: Technical Note: High-resolution mineralogical database of dust-productive soils for atmospheric dust modeling, Atmos. Chem. Phys., 12, 845-855, doi:10.5194/acp-12-8452012, 2012.
Nickovic, S., Vukovic, A., and Vujadinovic, M.: Atmospheric processing of iron carried by mineral dust, Atmos. Chem. Phys., 13, 9169-9181, doi:10.5194/acp-13-9169-2013, 2013.

Nozaki, Y.: A fresh look at element distribution in the North Pacific, EOS T. Am. Geophys. Un., 78, 221-221, doi:10.1029/97EO00148, 1997.

Okin, G. S., Mahowald, N., Chadwick, O. A., and Artaxo, P.: Impact of desert dust on the biogeochemistry Of phosphorus in terrestrial eco-systems, Global Biogeochem. Cy., 18, GB2005, doi:10.1029/2003GB002145, 2004.

Paris, R., Desboeufs, K. V., Formenti, P., Nava, S., and Chou, C.: Chemical characterisation of iron in dust and biomass burning aerosols during AMMA-SOP0/DABEX: implication for iron solubility, Atmos. Chem. Phys., 10, 4273-4282, doi:10.5194/acp10-4273-2010, 2010.

Paytan, A., Mackey, K., Chen, Y., Lima, I., Doney, S., Mahowald, N., Lablosa, R., and Post, A.: Toxicity of atmospheric aerosols on marine phytoplankton, P. Natl. Acad. Sci. USA, 106, 4601-4605, doi:10.1073/pnas.0811486106, 2009.

Perry, K. D., Cahill, T. A., Eldred, R. A., Dutcher, D. D., and Gill, T. E.: Long-range transport of North African dust to the eastern United States, J. Geophys. Res.-Atmos., 102, 11225-11238, 1997.

Petrucci, R. H., Herring, G., Madura, J., and Bissonnette C.: General Chemistry: Principles and Modern Application, 10th Edition, Printice Hall, New Jersey, Pearson Education, 1396 pp., 2011.

Prospero, J. M., Landing, W. M., and Schulz, M.: African dust deposition to Florida: temporal and spatial variability and comparisons to models, J. Geophys. Res., 115, D13304, doi:10.1029/2009JD012773, 2010.

Rasch, P., Coleman, D., Mahowald, N., Williamson, D., Lin, S.-J., Boville, B., and Hess, P.: Characteristics of atmospheric transport using three numerical formulations for atmospheric dynamics in a single GCM framework, J. Climate, 19, 2243-2266, 2006.

Reheis, M. C. and Kihl, R.: Dust deposition in southern Nevada and California, 1984-1989-relations to climate, source area, and source lithology, J. Geophys. Res.-Atmos., 100, 8893-8918, 1995.

Reid, E. A., Reid, J. S., Meier, M. M., Dunlap, M. R., Cli, S. S., Broumas, A., Perry, K., and Maring, H.: Characterization of African dust transported to Puerto Rico by individual particle and size segregated bulk analysis, J. Geophys. Res., 108, D19, doi:10.1029/2002JD002935, 2003.

Ridame, C. and Guieu, C.: Saharan input of phosphate to the oligotrophic water of the open western Mediterranean Sea, Limnol. Oceanogr., 47, 856-869, 2002.

Scanza, R. A., Mahowald, N., Ghan, S., Zender, C. S., Kok, J. F., Liu, X., Zhang, Y., and Albani, S.: Modeling dust as component minerals in the Community Atmosphere Model: development of framework and impact on radiative forcing, Atmos. Chem. Phys., 15, 537-561, doi:10.5194/acp-15-537-2015, 2015.

Schütz, L. and Rahn, K. A.: Trace element concentrations in erodible soils, Atmos. Environ., 16, 171-176, 1982.

Seinfeld, J. H. and Pandis, S. N.: Atmospheric Chemistry and Physics: from Air Pollution to Climate Change, J. Wiley, New York, 1326 pp., 1998. 
Shen, Z. X., Li, X., Cao, J., Caquineau, S., Wang, Y., and Zhang, $X$.: Characteristics of clay minerals in Asian dust and their environmental significance, China Part., 3, 260-264, 2005.

Shen, Z. X., Cao, J., Li, X., Okuda, T., Wang, Y., and Zhang, X.: Mass concentration and mineralogical characteristics of aerosolparticles collected at Dunhuang during ACE-Asia, Adv. Atmos. Sci., 23, 291-298, 2006.

Shen, Z. X., Cao, J. J., Arimoto, R., Zhang, R. J., Jie, D. M., Liu, S. X., and Zhu, C. S.: Chemical composition and source characterization of spring aerosol over Horqin sand land in northeastern China, J. Geophys. Res., 112, D14315, doi:10.1029/2006JD007991, 2007.

Sillanpää, M.: Micronutrients and the Nutrient Status of Soils: a Global Study, FAO Soils Bulletin, No. 48, Appendix 6-7, Rome, 1982.

Stoorvogel, J. J., VanBreemen, N., and Janssen, B. H.: The nutrient input by Harmattan dust to a forest ecosystem in Côte d'Ivoire, Africa, Biogeochemistry, 37, 145-157, 1997.

Sun, Y., Zhuang, G., Yuan, H., Zhang, X., and Guo, J.: Characteristics and sources of 2002 super dust storm in Beijing, Chinese Sci. Bull., 49, 698-705, 2004a.

Sun, Y., Zhuang, G., Wang, Y., Han, L., Guo, J., Dan, M., Zhang, W., Wang, Z., and Hao, Z.: The air-borne particulate pollution in Beijing - concentration, composition, distribution and sources, Atmos. Environ., 38, 5991-6004, 2004b.

Sun, Y., Zhuang, G., Wang Y., Zhao, X., Li, J., Wang, Z., and An, Z.: Chemical composition of dust storms in Beijing and implications for the mixing of mineral aerosol with pollution aerosol on the pathway, J. Geophys. Res., 110, D24209, doi:10.1029/2005JD006054, 2005.

Svensson, A., Biscaye, P. E., and Grousset, F. E.: Characterizationof late glacial continental dust in the Greenland Ice Core Project ice core, J. Geophys. Res., 105, 4637-4656, doi:10.1029/1999jd901093, 2000.

Swap, R., Garstang, M., Greco, S., Talbot, R., and Kallberg, P.: Saharan dust in the Amazon Basin, Tellus B, 44, 133-149, 1992.

Textor, C., Schulz, M., Guibert, S., Kinne, S., Balkanski, Y., Bauer, S., Berntsen, T., Berglen, T., Boucher, O., Chin, M., Dentener, F., Diehl, T., Easter, R., Feichter, H., Fillmore, D., Ghan, S., Ginoux, P., Gong, S., Grini, A., Hendricks, J., Horowitz, L., Huang, P., Isaksen, I., Iversen, I., Kloster, S., Koch, D., Kirkevåg, A., Kristjansson, J. E., Krol, M., Lauer, A., Lamarque, J. F., Liu, X., Montanaro, V., Myhre, G., Penner, J., Pitari, G., Reddy, S., Seland, Ø., Stier, P., Takemura, T., and Tie, X.: Analysis and $\mathrm{q}$ uantification of the diversities of aerosol life cycles within AeroCom, Atmos. Chem. Phys., 6, 1777-1813, doi:10.5194/acp-61777-2006, 2006.

Textor, C., Schulz, M., Guibert, S., Kinne, S., Balkanski, Y., Bauer, S., Berntsen, T., Berglen, T., Boucher, O., Chin, M., Dentener, F., Diehl, T., Feichter, J., Fillmore, D., Ginoux, P., Gong, S., Grini, A., Hendricks, J., Horowitz, L., Huang, P., Isaksen, I. S. A., Iversen, T., Kloster, S., Koch, D., Kirkevåg, A., Kristjansson, J. E., Krol, M., Lauer, A., Lamarque, J. F., Liu, X., Montanaro, V., Myhre, G., Penner, J. E., Pitari, G., Reddy, M. S., Seland, Ø., Stier, P., Takemura, T., and Tie, X.: The effect of harmonized emissions on aerosol properties in global models an AeroCom experiment, Atmos. Chem. Phys., 7, 4489-4501, doi:10.5194/acp-7-4489-2007, 2007.
Titschack, J., Goetz-Neunhoeer, F., and Neubauer, J.: Magnesium quantification in calcites $\left[(\mathrm{Ca}, \mathrm{Mg}) \mathrm{CO}_{3}\right]$ by Rietveld-based XRD analysis: revisiting a well-established method, Am. 5 Mineral., 96, 1028-1038, 2011.

Wang, Q., Zhuang, G., Li, J., Huang, K., Zhang, R., Jiang, Y., Lin, Y., and Fu, J. S.: Mixing of dust with pollution on the transport path of Asian dust - revealed from the aerosol over Yulin, the north edge of Loess Plateau, Sci. Total Environ., 409, 573-581, 2010.

Werner, M., Tegen, I., Harrison, S. P., Kohfeld, K. E., Prentice, I. C., Balkanski, Y., Rodhe, H., and Roelandt., C.: Seasonal and interannual variability of the mineral dust cycle under present and glacial climate conditions, J. Geophys. Res., 107, D244744, doi:10.1029/2002JD002365, 2002.

Wilke, B. M., Duke, B. J., and Jimoh, W. L. O.: Mineralogy and chemistry of Harmattan dust in northern Nigeria, Catena, 11, 9196, 1984.

Xuan J.: Emission inventory of eight elements, Fe, Al, K, Mg, Mn, $\mathrm{Na}, \mathrm{Ca}$ and $\mathrm{Ti}$, in dust source region of East Asia, Atmos. Environ., 39, 813-821, doi:10.1016/j.atmosenv.2004.10.029, 2005.

Yadav, S. and Rajamani, V.: Geochemistry of aerosols of northwestern part of India adjoining the Thar Desert, Geochim. Cosmochim. Ac., 68, 1975-1988, 2004.

Zender, C., Bian, H., and Newman, D.: Mineral Dust Entrainment and Deposition (DEAD) model: description and 1990s dust climatology, J. Geophys. Res., 108, D14, doi:10.1029/2002JD002775, 2003.

Zhang, X. Y., Arimoto, R., and An, Z. S.: Dust emission from Chinese desert sources linked to variation in atmospheric circulation, J. Geophys. Res., 102, 28041-28047, 1997.

Zhang, X. Y., Arimoto, R., Zhu, G. H., Chen, T., and Zhang, G. Y.: Concentration, size distribution and deposition of mineral aerosol over Chinese desert regions, Tellus B, 50, 317-330, 1998.

Zhang, X. Y., Gong, S. L., Shen, Z. X., Mei, F. M., Xi, X. X., Liu, L. C., Zhou, Z. J., Wang, D., Wang, Y. Q., and Cheng, Y.: Characterization of soil dust aerosol in China and its transport and distribution during 2001 ACE-Asia: 1. Network observations, J. Geophys. Res., 108, 4261, doi:10.1029/2002jd002632, 2003. 